\title{
WHO SUPPLIES PPP LOANS (AND DOES IT MATTER)? BANKS, RELATIONSHIPS AND THE COVID CRISIS
}

\author{
Lei Li \\ Philip Strahan \\ Working Paper 28286 \\ http://www.nber.org/papers/w28286 \\ NATIONAL BUREAU OF ECONOMIC RESEARCH \\ 1050 Massachusetts Avenue \\ Cambridge, MA 02138 \\ December 2020
}

The opinions in the paper do not represent those of the Federal Reserve Board of Governors, any other affiliate of the Federal Reserve System, or the National Bureau of Economic Research. We thank seminar participants at Boston College, the Federal Reserve Board of Governors, University of Minnesota and Southern Methodist University, as well as participants and our discussant Lawrence Schmidt at the TAU Conference on Financial Intermediation during the COVID-19 Crisis.

NBER working papers are circulated for discussion and comment purposes. They have not been peer-reviewed or been subject to the review by the NBER Board of Directors that accompanies official NBER publications.

(C) 2020 by Lei Li and Philip Strahan. All rights reserved. Short sections of text, not to exceed two paragraphs, may be quoted without explicit permission provided that full credit, including () notice, is given to the source. 
Who Supplies PPP Loans (And Does it Matter)? Banks, Relationships and the COVID Crisis

Lei Li and Philip Strahan

NBER Working Paper No. 28286

December 2020

JEL No. G2

\section{ABSTRACT}

We analyze bank supply of credit under the Paycheck Protection Program (PPP). The literature emphasizes relationships as a means to improve lender information, which helps banks manage credit risk. Despite imposing no risk, however, PPP supply reflects traditional measures of relationship lending: decreasing in bank size; increasing in prior experience, in commitment lending, and in core deposits. Our results suggest a new benefit of bank relationships, as they help firms access government-subsidized lending. Consistent with this benefit, we show that bank PPP supply, based on the structure of the local banking sector, alleviates increases in unemployment.

Lei Li

Federal Reserve Board of Governors

Washington, DC, DC

lei.li@frb.gov

Philip Strahan

Carroll School of Management

324B Fulton Hall

Boston College

Chestnut Hill, MA 02467

and NBER

philip.strahan@bc.edu 


\section{INTRODUCTION}

When governments intervene in the financial system and the economy, they often do so by influencing or bailing out banks. For example, in 1998 the Federal Reserve effected a private-sector bailout of the hedge fund Long-Term Capital Management through moral suasion of their main counterparties, banks. In 2008, the housing sector, which lay at the center of the crisis, did not receive a substantial bailout. Instead, banks - the primary provider of mortgage credit - were the focus of policy interventions with the Troubled Asset Relief Program and the first round of Quantitative Easing, as well as the Home Affordable Modification Program (HAMP) and the Home Affordable Refinance Program (HARP). ${ }^{1}$ In 2020, the Federal Reserve created the Main Street Lending program to help middle-market firms gain access to credit, but they did so by providing liquidity support to banks not to firms directly. Also in 2020, the Federal Reserve created the Money Market Mutual Fund Liquidity Facility, in which it uses banks to provide liquidity support to money funds. This paper uses micro evidence from the Paycheck Protection Program (PPP) to provide further evidence that banks act as the main conduit for access to government subsidies. We argue that our results provide a new (or perhaps unrecognized) rationale for the benefit to firms of close banking relationships.

We quantify the importance of banks in general, and relationship banks in particular, in supplying subsidized credit under the PPP program, created as part of the Coronavirus Aid, Relief, and Economic Security (CARES) Act. The PPP aims to help small businesses avoid laying off their workers during the peak of the COVID-19 economic crisis. We show that relationship banks supply more of this credit to their borrowers, and that localities with more

\footnotetext{
${ }^{1}$ For a critique of these actions, see Mian and Sufi (2014).
} 
relationship banking receive PPP credit earlier. As a result, these areas experience smaller increases in unemployment. Despite this intended effect of the PPP program, we find no evidence that broader measures of economic output - small business revenues or total spending respond to the program.

We start by asking: who supplies business credit during the COVID crisis? Aggregate figures provide a partial answer. As shown in Li et al. (2020), before the PPP program began in April, large banks respond to widespread demand for liquidity by large firms by expanding lending on an unprecedented scale during the last three weeks of the first quarter of 2020. During March, liquidity in money markets and bond markets becomes constrained, leading firms to 'run' to their banks and draw funds from pre-existing credit lines. This expansion in bank lending is evident in Figure 1, which compares cumulative loan growth for large versus small banks. After March, however, large banks experience contractions in lending as some large borrowers, with renewed access to liquidity from the markets, pay back their loans. ${ }^{2}$

Lending by small banks, who traditionally focus on relationship lending to small firms, grows sharply in April, reflecting their participation in the PPP program. Small and medium sized banks (those with assets under $\$ 50$ billion) provide about two thirds of the loans under the PPP program ( $\$ 310$ billion out of $\$ 494$ billion by all banks, or $63 \%$ ). This share exceeds their share of lending to small business before the COVID crisis, which was just $44 \%$ at the end of 2019. In contrast to PPP loans, new lending to business outside the PPP program stagnated for all banks during the second quarter. Figure 2 reports state-level heat maps of the quantity of PPP credit in the first round (April 3-17) and second round (April 27-August 9) of the program, along

\footnotetext{
${ }^{2}$ For further evidence on the effects of bond-market disruptions, see Acharya and Steffen (2020), Darmouni and Siani (2020), Chodorow-Reich et al. (2020), Greenwald et al. (2020), and Hotchkiss et al. (2020).
} 
with a similar one for the state prevalence of small banks. These figures suggest visually - and we verify in our regressions formally - the importance of relationship-oriented banks in getting the PPP credit to their borrowers immediately. States with more small banks received more PPP loans in the first round (correlation $=0.65$ ), whereas this relationship reverses sign in the second round (correlation $=-0.77)$.

Press accounts and anecdotal evidence suggest that firms with better access to banks before the COVID crisis were able to get PPP funding quickly at the outset of the program, which was overwhelmed with demand and had its first-round funds exhausted in just two weeks (Figure 3). ${ }^{3}$ This suggests that pre-COVID relationships became valuable by allowing firms close to their banks to gain access to the government subsidized lending, especially early in the implementation of the program. Because relationship banks have a long-term interest in the survival of their borrowers, they have an incentive to help those borrowers access the PPP program. Moreover, because relationship banks know their borrowers from prior interactions, application and other origination costs are likely lower for them.

To test this idea comprehensively, we focus on how bank characteristics explain their role in the PPP program. We estimate regressions based on quarterly Call Report data, which capture overall business lending as well as lending supplied by banks under the PPP program. We contrast lending patterns in March - which respond to the crisis in securities markets - with those in April and subsequent months - which respond to the economic downturn and the advent of government subsidies. Lending after March expands most at banks typically associated with close relationships with their borrowers. In particular, lending grows faster at small banks, at

\footnotetext{
${ }^{3}$ See for example, “PPP Money Abounded - But Some Got It Faster than Others,” Wall Street Journal, October 6, 2020.
} 
banks with high levels of small business loans prior to the crisis, at banks with high levels of unused business credit commitments before the crisis, and at banks raising more local, retail deposits. And, these effects are strongest at the smallest banks.

We then decompose business lending during Q2, 2020 into those made under the PPP program vs. all other business lending. Essentially all of the growth in lending during the second quarter comes under the PPP program, and all of the connections between relationship measures and lending growth reflects PPP lending (as opposed to other bank loans to business).

We validate the importance of relationships using two distinct empirical strategies. First, we separate each bank's PPP lending based on whether or not the borrower resides in one of the bank's core markets, defined as a county in which the bank owns at least one branch. As we show, the measures of relationships explain lending in core markets but only weakly in peripheral ones. We also show that the relationship variables matter most during the first round of PPP lending, consistent with the idea that banks advantaged their relationship borrowers over others by helping them access the PPP program first. Second, we report within-bank tests to compare lending as a function of bank branch and lending characteristics in their core markets. These tests show that banks lent more to PPP borrowers in their most important core markets (those where they made more small business loans prior to COVID). We also show that PPP lending increases with the average age of branches located in the core markets. The within-bank tests suggest that relationships from longstanding ties with the local economy affect PPP lending. That is, even after controlling for all cross-bank variation (with fixed effects), bank relationships still strongly predict their PPP credit supply.

In the last part of our analysis, we link PPP credit to local real outcomes. We show that variation in the quantity of PPP credit across counties reflects both the size and structure of local 
banks. Specifically, two pre-COVID measures of banking structure correlate strongly with the quantity of PPP credit across geographies, after controlling for demographic and economic covariates. First, and most simply, areas with more branches per eligible establishment (before COVID) receive more PPP credit. Second, areas with more local, relationship banks (based on our bank-level predictive model) also receive more PPP credit during the first round of allocations (the first two weeks of April). We use the relationship variable to capture local PPP credit supply conditions. Unlike the overall size of the local banking system, this variable reflects credit supply, not demand, because it correlates negatively with PPP credit from external banks. We then tie local PPP lending supply to real outcomes. Areas that receive more local PPP lending supply in the first round (because of the presence of relationship banks), we show, experience smaller increases in unemployment.

Several studies have assessed the impact of the PPP program on economic outcomes. For example, Granja et al. (2020) find that more PPP first-round funds flow into localities less affected by COVID, and that the effects of the PPP program on employment were small relative to the scale of the funds allocated. Autor et al. (2020) find evidence that employment falls less at firms eligible for PPP loans than at otherwise similar firms. Chetty et al. (2020) also find some evidence that PPP lending increases employment, but the effects are small relative to the cost of the program. Barraza et al. (2020) find that areas with more offices of banks that issued Small Business Administration (SBA) backed loans in 2019 experience smaller increases in unemployment after the initiation of the PPP program. Faulkender et al. (2020) also find a beneficial effect of PPP lending on unemployment, but one that is much larger than these other studies. Consistent with most of this literature, we also find that PPP supply helps preserve local employment. That said, our variation only compares unemployment patterns between counties 
based on whether or not they receive PPP loans in the first round. Ultimately, most PPP applicants did receive funds, as the program closed with over $\$ 100$ billion in unallocated funds. As such, we hesitate to use our approach to assess the effectiveness of the program itself. Instead, we use this last test to provide further evidence of the benefits of relationship lending, even when the government has removed all risk from credit providers.

Ours is the first paper we know of to study empirically how bank relationship characteristics relate to their overall supply of PPP loans. However, several recent papers have argued that bank relationships have helped firms gain access to PPP loans. Amiram and Rabetti (2020) focus on publicly traded firms and find that firms with existing banking relationship received larger PPP loans faster. Cororaton and Rosen (2020) also study publicly traded firms and find that smaller public firms with more employees, fewer investment opportunities, and COVID-19 exposure are more likely to borrow from PPP. Erel and Liebersohn (2020) find that borrowers in areas with fewer bank branches, lower incomes, and more minority population are more likely to access PPP via FinTech firms rather than banks. A number of studies show that small, community banks provide an outsized share of PPP loans (Balyuk (2020), Faulkender et al. (2020), James et al. (2020)). Bartik et al. (2020) use firm survey evidence, finding that firms with strong bank relationship are more likely to receive PPP loans, while Joaquim and Netto (2020) provide a theoretical analysis of bank incentives to lend under the program. ${ }^{4}$

Our paper contributes a new dimension to the literature on relationship banking. All of the extant banking literature emphasizes that relationships reduce information asymmetry about

\footnotetext{
${ }^{4}$ For evidence on government guaranteed lending outside the U.S., see Core and De Marco (2020).
} 
aspects of borrowers' ability or willingness to repay. ${ }^{5}$ Banks, the story goes, learn about their customer's business over time, monitor their cash flows and financial health, and lend based on a deep understanding of the business and its future prospects. PPP loans, in contrast, have no credit risk exposure for lending banks, yet relationships strongly predict PPP supply. Banks act as gatekeepers for the PPP program, shepherding small businesses through the application process. Banks prioritize their relationship borrowers over others because managing the application process is less costly for them, and because they have an economic interest in the long-term survival of their borrowers. ${ }^{6}$ Our results suggest that a close bank relationship can help firms gain access to the program and that such access has a real effect. Hence, our results point to a new benefit to firms of close relationships with banks: they help their close customers gain access to government subsidies. So, while existing studies document that relationships are valuable for conventional reasons (e.g., as shown in Bolton et al. (2016), relationship banks are more willing to stay with their borrowers during bad times), ours documents a less conventional but important reason (i.e., relationship banks help their borrowers gain access to government subsidies).

\footnotetext{
${ }^{5}$ There is a long literature on bank relationship lending which we will not review here. However, Petersen and Rajan (1994) is the seminal empirical analysis on the subject; they emphasizes the role of duration in relationship formation. Berger et al. (2005) and Degryse and Ongena (2005) provide evidence that distance between borrowers and banks provides another proxy for relationships, although Petersen and Rajan (2002) argue technology has reduced the importance of physical proximity to banks. Bank size has also been associated with relationship lending, motivated by Stein (2002), who argues that large complex organizations are less able to manage soft information embedded in lending relationships. The advent of technology has potentially limited the importance of these dimensions, as discussed in Berger and Black (2019). For a meta-analysis of the effects of relationships on the terms of bank loans, see Kysucky and Norden (2016).

${ }^{6}$ Humphries et al. (2020) use survey data to show that the smallest businesses face an information disadvantage in accessing PPP.
} 


\section{Background: The Paycheck Protection Program}

The negative economic impact of the coronavirus pandemic became increasingly evident in March 2020, as the spread of COVID-19 accelerated across the U.S. and states started to implement various emergency measures, including “lock-downs”. For the week ending on March 28, initial claims for unemployment insurance (seasonally adjusted) reached a historical high of 6.9 million. In response to this sharp and deep economic shock, the Congress quickly passed the Coronavirus Aid, Relief, and Economic Security (CARES) Act, which was signed into law on March 27th. The CARES Act provides a total of $\$ 2.2$ trillion in economic assistance for individuals, healthcare providers, businesses, and state and local governments. The Paycheck Protection Program (PPP), established under the CARES Act, aimed to help small businesses "maintain their payroll, hire back employees who may have been laid off, and cover applicable overhead.” The PPP program began to disburse funds on April 3. Strong initial demand exhausted the $\$ 350$ billion allocated within two weeks. An additional $\$ 320$ billion of funding was added to the PPP program by Paycheck Protection Program and Health Care Enhancement Act on April 24. The program closed to new loan applications on August 8, 2020, having distributed \$525 billion (Small Business Administration (2020)), although the majority of funds had been distributed by the early May (see Figure 3).

The PPP program provides loans to small businesses that are fully forgivable under certain conditions. Since the program's main aim is to reduce job separation, borrowers must maintain their employee and compensation levels to be eligible for forgiveness. ${ }^{7}$ Banks

\footnotetext{
${ }^{7}$ PPP loan forgiveness occurs under the following conditions: a) at least $75 \%$ of the loan proceeds cover payroll costs and the rest covers other overhead such as mortgage interest, rents, and utilities; and, b) the borrowers maintain their employee and compensation levels. See https://home.treasury.gov/policy-issues/cares/assistance-for-smallbusinesses for details.
} 
distributed most of the PPP loans. Initially, only existing Small Business Administration (SBA) lenders or federally insured depository institutions, credit unions, and Farm Credit System institutions could make PPP loans. The set of PPP lenders gradually expanded to include more non-bank lenders as the SBA approved their applications to participate. As of August 8, when the PPP loan application period ended, non-bank lenders account for only $8.3 \%$ of PPP loan count and 3.6\% of PPP loan amount (Small Business Administration (2020)). ${ }^{8}$

With a few exceptions, only businesses with fewer than 500 employees may apply for PPP loans. ${ }^{9}$ Potential borrowers submit applications directly to private PPP lenders, who review the application materials and fund the loans. All PPP loans have the same terms, with an interest rate of $1 \%$ and a maturity of two years for loans made before June 5 or five years for loans made on or after June 5. The SBA also pays lenders processing fees up to a limit for originating PPP loans. Once approved, the SBA guarantees repayment at no cost to the borrowers or lenders; this guarantee ultimately has backing of the full faith and credit of the U.S. Treasury. Hence, PPP loans carry a zero-percent risk weight under regulatory capital rules. In addition, the federal banking regulators (OCC, FDIC, and the Federal Reserve) issued a joint interim final rule on April 13 that effectively neutralizes the regulatory capital effects of PPP loans that are pledged by banks to the Paycheck Protection Program Lending Facility (PPPLF). Thus, regulated banks may originate PPP loans without any credit risk or marginal capital requirement.

\footnotetext{
${ }^{8}$ Those non-bank PPP lenders include small business lending companies, fintechs, non-bank CDFI funds, and other non-bank lenders.

${ }^{9}$ For example, firms in the accommodation and food services industry (with NAICS codes beginning with 72) are eligible for PPP loans if they employ less than 500 employees per physical location.
} 


\section{WHO SUPPLIES PPP LOANS?}

Data

We construct data on lending at the bank level by combining information from the Call Reports with information on the PPP program provided publicly by the U.S. Small Business Administration (SBA). The Call Report data normally capture bank lending to businesses both on and off the balance sheet (commercial and industrial (C\&I) loans and unused loan commitments to businesses). An additional field added to the 2020, Q2 Call Report also separates out lending under the PPP program. Thus, we can compare PPP lending with non-PPP, C\&I lending during 2020, Q2. These data capture all loans on bank balance sheets as of June 30, 2020.

The SBA data contain firm-level records of borrowing under the PPP program, with information on the location of the borrower, the size of the loan, and the name of the lender. We merge these data into the Call Report data using the name of the lender. This procedure allows us to match most of the banks exactly. Of the non-matched banks, about 400 made no PPP loans based on the Call Report data, so we assign zero PPP loans to these banks. Overall, we identify PPP lending for 4,333 out of 4,980 banks. Collectively, the matched banks cover $95 \%$ of the total PPP lending in the SBA database, so we are confident that our measures accurately represent the bulk of the program. Some of the residual PPP lending is made by banks which we could not match, and some by non-bank financial institutions such as Credit Unions and Community Development Financial Institutions.

In order to understand the role of bank relationships and the importance of local banks, we separate lending from the SBA data into loans made by banks with branches in the 
borrower’s county (deemed “core markets”), versus loans made by banks without local branches (deemed “peripheral markets”). To achieve this separation, we use the location of each bank's branches as of June 2019 from the Summary of Deposits dataset. ${ }^{10}$ Because the branch locations are set before the onset of COVID, we can safely assume that the definition of core vs. peripheral markets is exogenous. About $71 \%$ of the total lending made by the matched banks comes from core markets, and the other $29 \%$ from peripheral markets. The mean size of loans is slightly larger in core markets $(\$ 112,145)$ compared to peripheral markets $(\$ 100,321)$.

Table 1 reports summary statistics for bank-level measures of C\&I lending growth, total C\&I credit growth (loans plus unused commitments) and PPP loans. Unlike C\&I lending growth, total credit growth does not reflect variation in credit-line takedown (or repayments). We scale these and the other bank characteristics by total assets at the end of 2019. We also include bank characteristics as of Q4, 2019, which we use to explain the 2020 lending. Panel A reports lending growth during the first and second quarters of 2020; panel B reports summary statistics for PPP lending by lender size; and, Panel C reports the 2019 pre-COVID bank characteristics. $^{11}$

As shown in Figure 1, during 2020, Q1 C\&I lending grew rapidly at the largest banks, mainly from large increases in credit-line drawdowns during March (Li et al., 2020 and Chodorow-Reich, et al., 2020). The average bank, however, experienced a much smaller increase in C\&I lending (about 0.23-0.25 percentage points of assets). Business lending grew

\footnotetext{
${ }^{10}$ See https://www.fdic.gov/regulations/resources/call/sod.html.

${ }^{11}$ We relate lending in the first and second quarters of 2020 to 2019 bank covariates, but the sample changes slightly over the two periods. Table 1 reports the summary statistics for the Q2 sample, but the Q1 figures are nearly identical.
} 
much more rapidly in Q2, but only from the effects of the PPP program. Average PPP lending was $5.7 \%$ of assets. In contrast, non-PPP C\&I lending shrank by $0.2 \%$ of assets. When we separate lending into core vs. peripheral markets, we see similar amounts of lending. The average bank lends 3.4\% of assets to borrowers in its core markets, while lending $3.1 \%$ to borrowers in peripheral markets. As we will see, however, the emphasis on PPP lending to core markets is substantially higher for banks with strong local relationships. ${ }^{12}$ As shown in Panel B, PPP intensity per unit of assets is lower for the largest banks (mean=2.1\%), compared to medium-sized (mean=5.5\%) or small banks (mean=5.8\%).

In our second set of tests, we focus on county-level real outcomes. High frequency data are available online at the Opportunity Insights Economic Tracker website (https://tracktherecovery.org); Chetty et al. (2020) describe the data in detail. We focus on two of these outcomes (total revenue among small firms and total spending), as well as monthly unemployment rates at county level from the Bureau of Labor Statistics. ${ }^{13}$ Total revenues for small firms come from Womply. The series represents the percent change in net revenue, calculated each weekday as a seven-day moving average (seasonally adjusted), indexed to January 4-31, 2020. Small firms are defined as those meeting the SBA's threshold. ${ }^{14}$ Total spending at county level comes from daily aggregation of consumer spending based on debit and credit card transactions from Affinity Solutions.

\footnotetext{
12 The sum of lending to core plus peripheral markets exceeds total PPP lending from the Call Report because the former measures include lending through early August of 2020, while the Call Report figure only includes PPP lending through June 30.

${ }^{13}$ See https://www.bls.gov/lau/\#tables.

${ }^{14}$ To be specific, according the Chetty et al. (2020), "For each series, we construct daily values in exactly the same way that we constructed the consumer spending series. We first take a seven-day moving average, then seasonally adjust by dividing each calendar date's 2020 value by its corresponding value from 2019. Finally, we index relative to pre-COVID-19 by dividing the series by its average value over January 4-31.”
} 
Table 2 reports summary statistics for the real outcomes. Both small business revenue and spending grow during the first months of 2020, before the advent of the COVID crisis, and then fall sharply thereafter. The declines are sharpest in March and April when most states initiated lockdowns. Chetty et al. (2020) emphasize that the drop in spending is initially high across the income distribution. After passage of the CARES Act, however, spending increases sharply in low-income areas (though still below levels before COVID), but much less so in highincome areas. (Despite these spending patterns, unemployment has more adverse effects in lowincome areas.) As is clear in Table 2, unemployment increases sharply in April, then declines over the subsequent months. By the end of our sample, however, unemployment still well exceeds its level at the beginning of 2020.

\section{Business Lending during the COVID Crisis}

Tables 3-7 report regressions to explain bank lending during the 2020 COVID crisis. We first report models of overall C\&I lending; second, we subdivide the analysis into PPP vs. nonPPP, C\&I lending; third, we compare PPP lending patterns by bank size; fourth, we further subdivide PPP lending by market type (core vs. peripheral); and fifth, we report regressions at the bank-county level.

\section{The Cross Section of Bank Lending}

Table 3 reports the first of these tests, comparing the cross section of bank C\&I lending during the first and second quarters of 2020. As outcomes, we use the change in C\&I lending on balance sheet and the change in C\&I credit - the sum of lending on balance sheet plus unused business commitments - both scaled by Q4, 2019 assets. 
We measure all bank characteristics from the Q4, 2019 Call Reports and June 2019 Summary of Deposits. As such, they are unaffected by the COVID crisis. We separate bank characteristics into three tiers. First, we consider measures which the prior literature has associated with bank-firm relationship lending: Unused commitments (undrawn loan commitments to businesses/assets), Small business loans (C\&I loans under \$1 million/assets), and Core deposits (transaction deposits plus insured time deposits/assets). For example, Petersen and Rajan (1994) is the first study to document the importance of relationships for bank lending to small firms. Berger and Udell (1995) show, using similar data, show that credit lines (which generate undrawn loan commitments to business) are more associated with close bank-borrower relationships than term lending. Norden and Weber (2010) find that credit lines usage help banks forecast default. Berlin and Mester (1999) show that core deposits help foster relationship lending by allowing banks to cross subsidize borrowers over the credit cycle. ${ }^{15}$ Second, we include three additional measures of bank balance sheets: the ratio of total C\&I lending to assets (C\&I lending), cash plus securities to assets (Liquid assets), and Tier 1 leverage ratio (Tier 1 Capital). C\&I lending captures variation in bank overall emphasis on lending to business, whereas the other two measures capture variation in the financial strength of the bank. Third, we include two additional bank characteristics: Bank size (the log of total assets) and Bank age (the log of the deposit-weighted average age of the bank's branches). Panel C of Table 1 provides summary statistics for these explanatory variables. The deposit-weighted COVID death rate is derived from county-level COVID death rates obtained from the Opportunity Insights Economic

\footnotetext{
${ }^{15}$ The theoretical idea that bank deposits provide information to lenders goes back further, to Fama (1985). For more recent empirical evidence, see Yang (2020).
} 
Tracker website within a bank's branch network. All variables, except Bank size, are winsorized at the 1st and 99th percentiles.

Table 3 shows sharp differences in lending patterns between the first and second quarters of 2020, particular for the effect of the three relationship characteristics. In Q1, Unused commitments strongly correlates with C\&I lending growth (Column 1). As Li et al. (2020) show, the largest banks drive this result; these banks face unexpected increases in credit-line takedowns from their large borrowers who lose access to short-term funding markets and the bond market. Credit-line takedowns have no effect on total credit originations, however, which explains why Unused commitments has no significance in Column (2). In Q2, the effect of Unused commitments increases relative to Q1 (by a factor of eight). In contrast to Q1, both Small business loans and Core deposits affect lending strongly in Q2. We know that these effects represent new credit originations, rather than credit-line takedowns, because both C\&I lending growth and C\&I credit growth respond similarly. Economic magnitudes are substantial. A onestandard deviation increase raises C\&I lending by $1.7 \%$ of assets (Unused commitment), $0.6 \%$ of assets (Core deposits), and $0.5 \%$ of assets (Small business loans). For comparison, C\&I lending grew by $5.4 \%$ of assets on average during the period. Beyond the relationship variables, we also find that banks with higher Liquid assets increased lending less than other banks in Q2, as did larger banks and older banks.

Table 4 focuses on the difference between PPP lending patterns with those of other unsubsidized C\&I lending (for Q2, 2020 only). PPP lending, as this comparison shows, drives the sharp differences in lending patterns between the first and second quarters. As in Q1, most of the correlations between bank characteristics and non-PPP, C\&I lending are weak. The exception is Unused commitments, which has a negative impact on non-PPP C\&I lending (but no 
effect on non-PPP total credit). This reflects firms, who had drawn funds during the March financial-market meltdown, repaying those funds as bond-market access came back online (see Chodorow-Reich et al. (2020) and Darmouni and Siani (2020)).

In Q2, the three relationship measures have very strong power to explain PPP lending (and the sign of the coefficient on Unused commitments becomes positive). This is interesting because PPP loans do not expose banks to credit risk. The U.S. government bears the downside risk. As such, this finding points to a benefit of banking relationships not emphasized before in the existing literature: firms with strong bank relationships receive better access to the PPP credit, probably because many banks have limited capacity to help firms manage the application process, and this limited capacity is deployed first in the service of the bank's relationship borrowers. ${ }^{16}$

Table 5 reports estimates of these models separately for small ( $<\$ 10$ billion in assets), medium-sized ( $\$ 10$ to $\$ 50$ billion in assets) and large ( $>\$ 50$ billion in assets) banks. This split further supports the relationship-banking interpretation. First, the largest banks, which focus much less on small relationship borrowers, lend much less in the PPP program per unit of assets than other bank (recall Table 1, Panel C). Second, the large banks exhibit little effect of the three relationship measures on PPP lending. Unused commitments and Small business lending are both insignificant in the regression. In contrast, both Unused commitments and Small business lending are very strongly tied to PPP lending for medium-sized and small banks. Core deposits only exhibits a strong connection to PPP for the small banks.

\footnotetext{
${ }^{16}$ According to press accounts about the PPP, “...the program’s expenses were also high, the big banks said. Bank of America devoted 10,000 employees to making loans at the program's peak, Mr. Moynihan said in July, and expects the next stage of the program - helping companies through the paperwork to have their loans forgiven, if they qualify — to be complicated and time consuming." See New York Times, "Despite Billions in Fees, Banks Predict Meager Profits on P.P.P. Loans," October 1, 2020.
} 
Pinning down the Role of Relationships: Bank Lending by Market and Branch Characteristics

We have shown that bank lending during Q2, 2020 exhibits a strong link to pre-COVID measures of bank relationships. The links shift sharply between the first (pre-PPP) and second (post-PPP) quarters; the links in the second quarter are only evident in the PPP lending, not in other C\&I lending; and, the links are strongest for smaller banks. All of these point to an important role of relationships for the supply of PPP credit. But all of these tests are just crossbank correlations. To rule out alternative explanations due to unobserved heterogeneity across banks, we now compare PPP lending by market type (core vs. peripheral), and then by withinbank measures of the strength of its relationships with local borrowers.

Table 6 reports regressions of PPP lending in core and peripheral markets separately, along with the difference between them. The regressions include the same set of explanatory variables as in Tables 3-5, but we focus only on the effects of the relationship dimensions. We report each set of regressions first on all banks, and then split based on bank size. Each of the three measures - Unused commitments, Small business lending, and Core deposits - affects PPP lending in core markets more than in peripheral ones. In fact, two of the three measures have no power to explain PPP lending in the peripheral areas. Lending in core markets most likely reflects bank interactions with their relationship clientele, and measures of the strength of the relationships only matter in those areas. As in the earlier split by bank size, the effects are evident in small and medium-sized banks, but not among the largest banks.

Table 6 also reports the same set of regressions, with the dependent variable split based on first-round versus second-round lending (Panels B and C). This split shows the same directional effects: more PPP lending by relationship banks. But it also shows much larger coefficient magnitudes during the first round. The importance to firms of having a close bank 
relationship thus manifests most strongly in the first round as banks put their closest customers to the front of then line in applying to the SBA. As we discussed earlier, the PPP funds ran out in just two weeks, leading to additional legislation to fund the second round (Figure 3).

In Table 7, we change the structure of the data to focus on how banks supply PPP lending across their core markets. In particular, we estimate regressions with the following structure:

$$
\begin{aligned}
& (\text { PPP Lending/Assets })_{i, j}=\alpha_{i}+\gamma_{j}+\beta^{1}(\% \text { Bank Deposits from County })_{i, j}+ \\
& \beta^{2}(\text { Log Branch Age })_{i, j}+\beta^{3}(\% \text { County Deposits from Bank })_{i, j}+ \\
& \beta^{4}(\% \text { Bank CRA Loans in County })_{i, j}+\beta^{5}(\% \text { County CRA Loans from Bank })_{i, j}+\varepsilon_{i, j},
\end{aligned}
$$

where $i$ represents bank and $j$ represents county. The restructured data disaggregate each bank’s total PPP lending in its core markets (one outcome in Table 6) into one observation for each county in which the bank owns at least one branch. As such, summing the outcome in Equation (1) across all counties for a given bank recovers that bank’s total PPP lending in its core markets. The lending measures, built from bank-county data collected under the Community Reinvestment Act (CRA), are only available for banks with more than $\$ 1$ billion in assets. Thus, we report the models with and without the two variables representing bank lending.

We remove all county-level variation in Equation (1) with a county fixed effect $\left(\gamma_{j}\right)$, and all bank-level variation with a bank effect $\left(\alpha_{i}\right)$. Including the county fixed effect removes variation related to local demand for PPP loans such as differences in exposure to COVID or other sources of variation. Including the bank fixed effect removes variation related to bank heterogeneity. Equation (1) compares PPP lending for the same bank operating in different counties. This allows us to test whether banks lend more where they raise more deposits or make more loans $\left(\beta^{1}\right.$ and $\left.\beta^{4}\right)$, whether banks lend more where their branches are older $\left(\beta^{2}\right)$, and 
whether banks lend more where their market share is higher $\left(\beta^{3}\right.$ and $\left.\beta^{5}\right)$. If relationships affect bank supply of PPP credit, we would expect all of these effects to load positively.

Table 7 offers strong support that banks supply more PPP credit in areas where they have stronger relationships with local borrowers. That is, banks increase their supply of PPP loans in markets where they have more deposit market share; they increase PPP loans in markets where their branches are older; and, they increase PPP loans in markets where they lend a greater percentage of those funds. These results suggest that PPP lending increases more in areas that are more important to the lender, based on banks' pre-COVID experience. The effect of branch age provides very strong evidence for the importance of relationships, as the literature emphasizes the importance of relationship length in fostering close bank-borrower ties (e.g., Petersen and Rajan, 1994). ${ }^{17}$

\section{RELATIONSHIP LENDING, PPP LOAN SUPPLY AND REAL EFFECTS}

To test how bank supply of PPP loans affects real outcomes, we first estimate the impact of the size and structure of the local banking sector on the quantity of PPP lending at the county level. We test how these effects break down between core-market bank lending (banks with branches in the county) and peripheral-market bank lending, and also how they break down by time (first v. second rounds of PPP funds). We then report regressions of county-level real outcomes on PPP credit measures based on the pre-COVID structure of the local banking system.

\section{County-Level PPP lending}

\footnotetext{
${ }^{17}$ In our bank-level regressions, we find the opposite. That is, younger banks make more PPP loans. This result represents variation across banks. As such, it suggests that new banks without relationship capital are using the PPP program to find new customers.
} 
To document how local bank structure affects overall PPP credit supply, we regress county-level PPP lending (scaled by the number of establishments with fewer than 500 employees) on two measures of local bank structure (controlling for other county level factors plausibly related to demand). The regression structure follows:

$$
\begin{aligned}
& \text { PPP Loans/Estab.j }=\beta^{1}{\text { Branches } / \text { Estab }_{. j}+\beta^{2} \text { Predicted PPP Lending }}_{j} \\
& + \text { Demand Controls }+\varepsilon_{j} .
\end{aligned}
$$

We then sub-divide county PPP lending into four sub-components: based on time (first round PPP v. second round) and based on core (lenders with branches in the borrower's county) v. peripheral providers of credit.

Equation (2) varies across counties (j). The outcome, PPP Loans/Establishment, which we measure in thousands of dollars per establishment, averages about $\$ 70$. Branches /Establishment; , equal to the total number of bank branches per establishment in county $j$, measures total banking capacity before COVID (June 2019), relative to a proxy for the number of firms eligible for PPP loans. ${ }^{18}$ Predicted PPP Lending equals the weighted average of each bank's predicted bank-level (PPP Lending/Assetsi) in their core markets, with weights equal to bank i's share of total deposits in county $j$ from 2019. Using the model from Panel A of Table 6 (columns 4, 7, and 10), PPP Lending/Assets $j_{j}$ is a linear combination of the characteristics of the banks operating in county $j$. Since our bank-level model finds strong explanatory power from relationship characteristics, this variable will be high in areas where relationship lenders hold a

\footnotetext{
${ }^{18}$ We do not have a count of eligible firms, so we use the number of establishments with fewer than 500 employees as a close proxy. These data come from the 2018 County Business Patterns data, provided by the U.S. Census Bureau.
} 
high percentage of total deposits. Moreover, this variable is predetermined because the regression in Table 6 includes only bank covariates from the end of 2019 or earlier.

Equation (2) also includes demographic characteristic of the county (log of county population; the fraction of the population with a college degree or better; the fraction of the population aged 20 to 44), as well as measures of the strength of the local economy (the log of median income in the county from 2018 and the unemployment rate from 2019). These data come from the U.S. Census and USDA. ${ }^{19}$ In addition, we include the COVID death rate. ${ }^{20}$ These variables help remove variation due to demand for PPP loans.

Equation (2) achieves two objectives. First, it allows us to assess whether or not the size of the local banking sector affects PPP credit supply (as opposed to PPP funds flowing frictionlessly across geographies). Second, we can assess the importance of not just the size but also the structure of local banks. As we have seen, small banks, banks focusing on small business lending, and banks with high levels of unused business loan commitments originate more PPP loans; Predicted PPP Lending captures these effects. To summarize, if areas with more local bank branches receive greater supply of PPP loans, then $\beta^{1}>0$. If the types of banks matters, then $\beta^{2}>0$.

We use Equation (2) as a first-stage regression to show that variation in predetermined measures of banking structure affects the quantity of PPP credit. To document that these are valid measures of supply (rather than demand), we split the outcome based on PPP lending from banks locating in the county (core-market banks) v. PPP lending by banks not located in the

\footnotetext{
${ }^{19}$ County level education, unemployment, and median household income data are from https://www.ers.usda.gov/data-products/county-level-data-sets/download-data/ and all other demographics data from https://www.census.gov/data/datasets/time-series/demo/popest/2010s-counties-detail.html.
}

${ }^{20}$ Data are obtained from the Opportunity Insights Economic Tracker website (https://tracktherecovery.org). 
county (peripheral-market banks). Lending from peripheral-market banks will increase with PPP demand. Hence, if there is no positive effect of Branches/Establishment or Predicted PPP Lending on lending by peripheral banks, then we can rule out a spurious correlation with PPP demand.

Column (1) of Table 8 reports estimates of Equation (2). We find strong evidence that areas with more local bank branches receive more PPP loans; i.e., $\beta^{1}>0$ (significant at $1 \%$ level). The magnitude is also substantial. A one-standard deviation increase in Branches/Establishment (=0.02), for example, is associated with an increase in PPP lending of about $\$ 18,000$ per establishment ( $=0.02 \times 888.6 \times 1000)$, or a little less than $30 \%$ of the mean $(=\sim \$ 70,000)$. Predicted PPP Lending has a positive but insignificant coefficient, however.

Columns (2)-(5) of Table 8 separate the outcome between the first and second rounds of PPP lending (recall Figure 3) and between core v. peripheral markets. This four-way split suggests that both the size of the local banking system (Branches/Establishment) and its structure (Predicted PPP Lending) increase the quantity of PPP loans in the first round (Column 2). Columns (3)-(5) help us assess the (identification) claim that the banking structure variables capture PPP supply. In contrast to Predicted PPP Lending, Branches/Establishment covaries positively with PPP loans from peripheral lenders in both the first and second rounds. This suggests a critical identification concern: areas with more bank branches (pre-COVID) contain more firms reliant on bank credit (i.e., greater demand for PPP loans). Hence, the number of bank branches cannot be used to assess PPP credit supply. In contrast, Predicted PPP Lending loads negatively in Columns (3)-(5), meaning that some firms, unable to borrow locally in the first round (because their market contains too few relationship lenders), were able to get credit from peripheral banks. Thus, Predicted PPP Lending predicts early access to the PPP program 
(Column (2). Borrowers in areas with higher Predicted PPP Lending move to the 'front of the line’ and receive credit early from their relationship lender.

Small Business Revenues, Local Spending, and Unemployment

To test whether PPP credit supply from relationship lenders has real effects, we model three outcomes: daily Small business revenue; daily Local spending; and, monthly Unemployment rate. We construct panel data at the county-time level, from the beginning of 2020 through July. This sample incorporates a pre-COVID period, a period of transition in which the effects of COVID pushed financial markets into turmoil (most of March), and a period in which policy steps from the CARES Act had gone into effect (April and the subsequent months). Our model tests how measures of local demographics, local pre-COVID economic variables, and PPP credit supply affect real outcomes across these shifting periods. Specifically, we estimate the following models:

$$
\begin{array}{r}
Y_{j, t}=\alpha_{t, s}+\gamma_{j}+\Sigma \beta^{k}\left(I_{t}{ }^{k} \times \text { Predicted PPP Lending } j\right) \\
+\Sigma \gamma^{k}\left(I_{t}{ }^{k} \times \text { Demo. \& Econ. controls } j\right)+\varepsilon_{j, t .} .
\end{array}
$$

In Equation (3), $j$ represents county and $t$ represents time (either day or month). $Y_{j, t}$ represents each of our three outcomes. We remove aggregate shocks with the state-time effect $(\alpha t, s)$ and all cross-county heterogeneity with the county effect $\left(\gamma_{j}\right)$. All county characteristics, including Predicted PPP Lending, vary only in the cross section, so the county effect absorbs their direct impact on outcomes.

We focus on how Predicted PPP Lending affects outcomes as the COVID crisis emerges, and then as the policy actions come online. In addition, we control for other county-level 
variables to absorb as much variation in demand for PPP credit as well as the effects of the COVID crisis on outcomes. Hence, we interact each county characteristic with $I_{\mathrm{t}}{ }^{\mathrm{k}}$, defined as five monthly indicators. ${ }^{21}$ The first indicator (March) equals one prior to beginning of the PPP program but after the onset of the COVID crisis. ${ }^{22}$ The last four indicators correspond to calendar months during the period in which the PPP program distributes funds. The coefficients $\beta^{k}$ test for systematic shifts in the impact of Predicted PPP Lending (and the other county characteristics) during these one-month periods, relative to the omitted period (January and February). If the relationship lenders help firms, then $\beta^{k}$ ought to be positive for both Small business revenue and Local spending during April-July, and negative for the Unemployment rate. The effects measured during the Crisis period represent "placebo" tests because the PPP program had not yet come online then. This helps us assess the plausibility of the model. ${ }^{23}$

Equation (3) represents a reduced form, which directly links a supply instrument (Predicted PPP Lending) to the real outcomes. We could have structured this analysis as on instrumental variables model, with PPP Loans/Establishment modeled as the endogenous regressor. However, if the structure of the local banking system affects economic outcomes in ways that go beyond the PPP program, then these instruments might fail the exclusion restriction. While this may be true, and while additional effects cannot be fully ruled out, lending patterns suggests otherwise. First, the PPP program dominates new credit originated during the AprilJuly 2020. For example, non-PPP C\&I lending fell during the second quarter of 2020 (Table 1).

\footnotetext{
${ }^{21}$ The PPP program closed to new applications on August 8, just a few days after the end of our sample, so we end our analysis in July.

22 The World Health Organization declared as a global pandemic on March 11, 2020.

${ }^{23}$ We double cluster by time (or state-time in the case of the unemployment rate, due to the small number of time units) and county to construct standard errors.
} 
Second, as we will see, the time series pattern of the effects of banking line up with the timing of the PPP program.

Table 9 reports the estimates of Equation (3). We find little impact of Predicted PPP lending on either Small business revenues or Total Spending. Sign patterns are positive, consistent with benefits, but with minimal joint statistical significance (F-statistics around 1 for the April-July coefficients). In contrast, we find very strong statistical evidence that Unemployment rate is lower in markets with more relationship lenders (i.e., higher Predicted PPP lending). Coefficients become strongly negative in May, and they increase in magnitude in June and July, with high joint statistical significance $(\mathrm{F}$-statistic $=8.13)$. The time patterns of our estimates in the reduced form are consistent with our core arguments. That is, there is no evidence of "pre-trends" in the data. The coefficient on Predicted PPP loans is small and not statistically significant in March 2020, as they should be because the PPP program had yet to begin. ${ }^{24}$

While counties with higher Predicted PPP lending do experience less unemployment after the advent of the PPP program, the economic impact is small. For example, increasing Predicted PPP lending by one standard deviation (= 0.014) lowers the unemployment rate in June by just 0.21 percentage points $(=-0.014 x 15.2)$; this decline is dwarfed by the average increase in unemployment of 7.6 percentage points between March and April. Moreover, we find no broader benefits, either to small businesses themselves (in terms of sales or revenues), or in terms of total spending. The small economic magnitude likely reflects the fact that the second

\footnotetext{
${ }^{24}$ March 2020 represents a fairly strong placebo period because banks were important during that time in alleviating the stresses on large firms due to the disruptions in the money markets and the bond market. Thus, if we observe no effects on local outcomes before April, this supports the claim that the effects observed after April in fact stem from the PPP program.
} 
round of PPP funding was sufficiently generous that all firms demanding these loans eventually received them. That said, the evidence does suggest that relationship lending, by giving firms early access to the PPP program, did help them avoid laying off workers.

\section{CONCLUSION}

This paper analyzes the role of banks as the primary conduit of funds for the Paycheck Protection Program. We find that PPP lending by banks increases with traditional measures of relationship lending: larger for small banks, increasing in prior experience in the local market, increasing in commitment lending, and increasing in core deposits. The traditional rationale for bank relationships - access to soft information, which mitigates asymmetric information problems - cannot explain our findings because banks face no credit risk in making PPP loans. Thus, our results suggest a new benefit to firms of close ties to their banks, which are often the key conduit for access to government subsidies. Using our model of bank-level lending, we build a local supply measure that reflect the structure of the banking systems. We find that increases in this predicted PPP lending, which reflects the presence of relationship-oriented banks prior to COVID, lowers local unemployment.

Our results point to an inefficiency in the distribution of PPP funds, as firms with banking relationships receive earlier access to credit, irrespective of merit. Distributing the $\$ 525$ billion in funds so quickly - just one month - could only be achieved using the human capital employed by the banking system. Government interventions or bailouts have often historically worked through the banking system. We have seen this not only with the PPP program, but in other ways in which the Federal Reserve intervened during the COVID crisis, in its interventions during the 2008 Global Financial Crisis, and also in its actions to stem bond-market disruptions during 1998. Why do government interventions work though banks, rather than just helping whatever 
economic entity is most distressed? The answer may reflect an unpleasant tradeoff between the short-term benefits of interventions (e.g., ending a financial panic) vs. the longer run moral hazard costs. Using the banking system as the conduit may be a way to limit the scope of interventions and thus limit the associated moral hazard costs. 


\section{REFERENCES}

Acharya, V. V., and S. Steffen. 2020, “The risk of being a fallen angel and the corporate dash for cash in the midst of COVID,” forthcoming in the Review of Corporate Finance Studies.

Autor, David, David Choz, Leland D. Cranez, Mita Goldarx, Byron Lutzz, Joshua Montesz, William B. Petermanz, David Ratnerz, Daniel Villarz, and Ahu Yildirmazx, 2020, “An Evaluation of the Paycheck Protection Program Using Administrative Payroll Microdata,” MIT Working paper.

Amiram, Dan and Rabetti, Daniel, “The Relevance of Relationship Lending in Times of Crisis,” (September 2020). Available at SSRN: https://ssrn.com/abstract=3701587.

Berger, Allen and Udell, Gregory, 1995 "Relationship lending and lines of credit in small firm finance,” Journal of Business 68, 351-82.

Berger, Allen, Nathan Miller, Mitchell Petersen, Raghuram Rajan and Jeremy Stein, 2005, “Does Function follow Form? Evidence from the Lending Practices of Large and Small Banks,” Journal of Financial Economics 76(2), 237-69.

Berger, Allen N. and Lamont K. Black, 2019, "Small Business Lending: The Roles of Technology and Regulation from Pre-Crisis to Crisis to Recovery," in Oxford Handbook of Banking, Third Edition, Allen N. Berger, Philip Molyneux, and John O.S. Wilson, editors, Oxford University Press, Oxford, (2019) 431-469.

Balyuk, Tatyana, Nagpurnanand R. Prabhala \& Manju Puri, 2020, “Intermediary Supply Effects: Lessons From the Paycheck Protection Program,” NBER Working Paper no. 28114.

Bartik, Alexander, Cullen, Zoe, Glaeser, Edward L., Luca, Michael, Stanton, Christopher and

Sunderam, Aditya, 2020, “The Targeting and Impact of Paycheck Protection Program Loans to Small Businesses,” NBER Working Paper No. w27623.

Barraza, Santiago, Rossi, Martin and Yeager, Timothy J., 2020, “The Short-Term Effect of the Paycheck Protection Program on Unemployment,” Available at SSRN: https://ssrn.com/abstract=3667431.

Berlin, Mitchell and Loretta J. Mester, 1999, “Deposits and Relationship Lending,” Review of Financial Studies 12(3), 579-607.

Bolton, Patrick, Xavier Freixas, Leonardo Gambacorta, Paolo Emilio Mistrulli, 2016, "Relationship and Transaction Lending in a Crisis," Review of Financial Studies 29(10), 26432676.

Chodorow-Reich, Gabrial, Olivier Darmouni, Stephan Luck and Matthew Plosser, 2020, “Bank Liquidity Provision Across the Firm Size Distribution,” Available at SSRN: https://papers.ssrn.com/sol3/papers.cfm?abstract_id=3702725. 
Core, Fabrizio and Felippo De Marco, 2020, "Public Guarantees for Small Businesses in Italy during COVID-19," Available at SSRN:

https://papers.ssrn.com/sol3/papers.cfm?abstract_id=3604114.

Cororaton, Anna and Rosen, Samuel, 2020, "Public Firm Borrowers of the US Paycheck Protection Program,” SMU Cox School of Business Research Paper No. 20-01, Available at SSRN: https://ssrn.com/abstract=3590913.

Darmouni, Olivier and Kerry Siani, 2020, "Crowding Out Bank Loans: Liquidity-Driven Bond Issuance,” Available at SSRN: https://papers.ssrn.com/sol3/papers.cfm?abstract_id=3693282.

Degryse, H., Ongena, S., 2005, “Distance, lending relationships, and competition,” Journal of Finance, 60 (1), 231-266

Erel, Isil and Liebersohn, Jack, 2020, "Does FinTech Substitute for Banks? Evidence from the Paycheck Protection Program,” NBER Working Paper no. 27659.

Fama, Eugene, 1985, “What’s Different about Bank?” Journal of Monetary Economics 15(1), 29-39.

Faulkender, Michael, Robert Jackman and Stephen Miran, 2020, "The Job-Preservation Effects of Paycheck Protection Program Loans,” US Treasury, Office of Economic Policy Working Paper 2020-01.

Granja, Joao and Makridis, Christos and Yannelis, Constantine and Zwick, Eric, 2020, "Did the Paycheck Protection Program Hit the Target?” Available at SSRN:

https://ssrn.com/abstract=3585258.

Greenwald, Daniel, John Krainer, and Pascal Paul, 2020, “The Credit Line Channel,” San Francisco Fed Working Paper 2020-26.

Hotchkiss, Edith, Greg Nini, and David C. Smith, 2020, "Corporate Capital Raising During the COVID Crisis,” https://papers.ssrn.com/sol3/papers.cfm?abstract_id=3723001.

James, Christopher M. and Lu, Jing and Sun, Yangfan, 2020, “Time Is Money: Relationship Lending and the Role of Community Banks in the Paycheck Protection Program.” Available at SSRN: https://ssrn.com/abstract=3633339.

Joaquim, Gustavo and Netto, Felipe, 2020, "Bank Incentives and the Impact of the Paycheck Protection Program.” Available at SSRN: https://ssrn.com/abstract=3704518.

Kysucky, V. and Lars Norden, 2016, “The Benefits of Relationship Lending in a Cross-Country Context: A Meta-Analysis,” Management Science 62, 90-110.

Humphries, John Eric and Neilson, Christopher and Ulyssea, Gabriel, 2020, "Information Frictions and Access to the Paycheck Protection Program," Cowles Foundation Discussion Paper 2247, NYU Stern School of Business, Available at SSRN: https://ssrn.com/abstract=3667636.

Li, Lei, Strahan, Philip E. and Zhang, Song, 2020, "Banks as Lenders of First Resort: Evidence from the COVID-19 Crisis," forthcoming at the Review of Corporate Finance Studies.

Mian, Atif and Amir Sufi, 2014, House of Debt, University of Chicago Press. 
Peterson, Mitchell, and Raghuram Rajan, 1994. “The benefits of firm-creditor relationships: Evidence from small-business data,” Journal of Finance, Vol. 49, 3-37.

Peterson, Mitchell, and Raghuram Rajan, 2002. “Does Distance still Matter,” Journal of Finance, Vol. 57, 2533-2570.

Stein, Jeremy, 2002, "Information Production and Capital Allocation: Hierarchical vs. Decentralized Firms,” Journal of Finance 57, 1891-1921.

Yang, Jun, 2020, “Deposit-Lending Synergies: Evidence from Chinese Students at US Universities,” Available at SSRN: https://papers.ssrn.com/sol3/papers.cfm?abstract_id=3281397. 


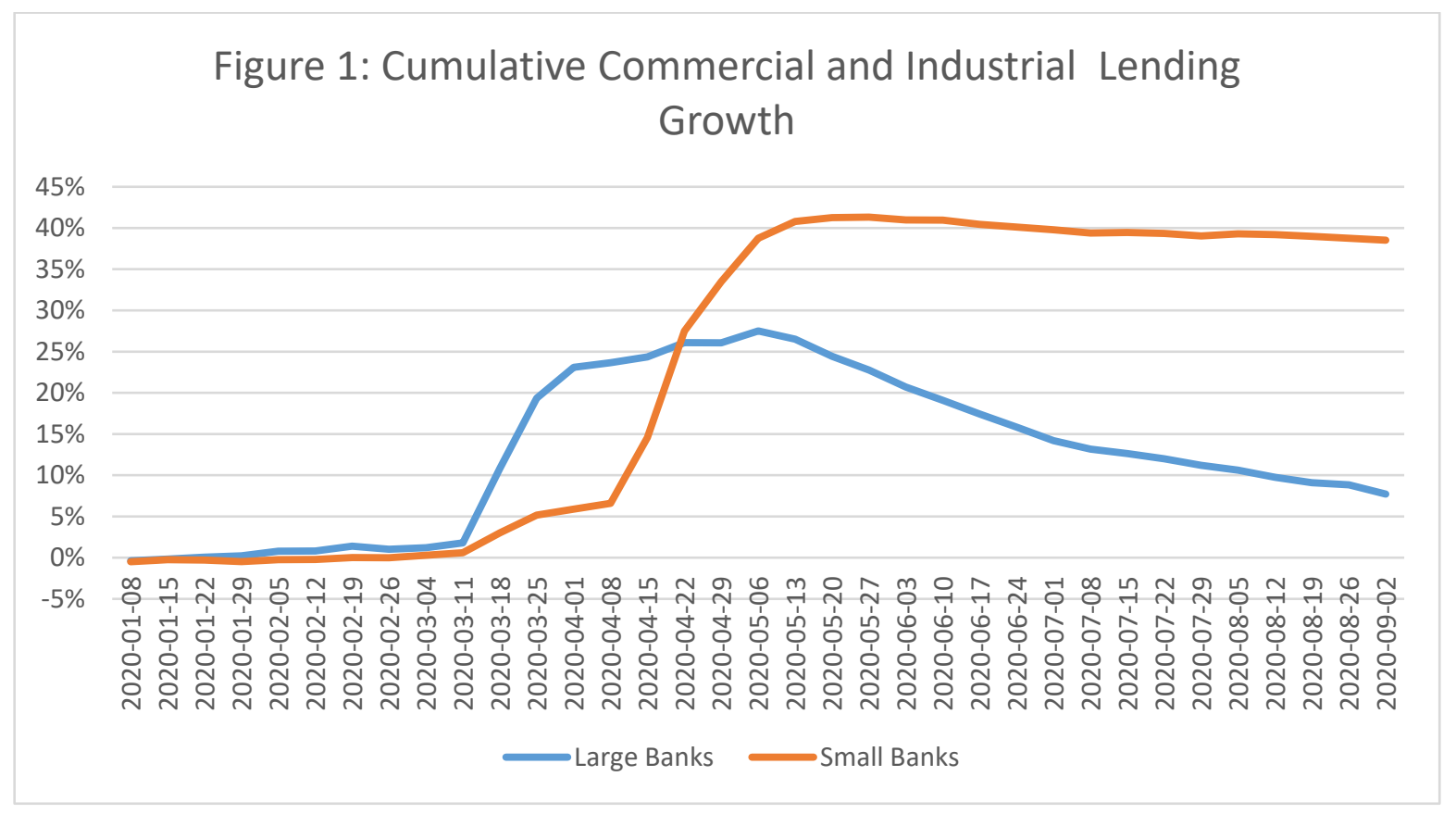

This figure plots the cumulative commercial and industrial loan growth since January 2020 at large and small banks in the U.S. The data come from the Federal Reserve's H.8 weekly statistical release. Large banks are the top 25 domestically chartered commercial banks by assets and small banks include the rest of the banks. 
Panel A of Figure 2 plots the heat map of state-level total PPP loan amount (in dollars) received during the first round of PPP (April 3-16) scaled by the number of establishments with less than 500 employees in 2018 . Panel B of Figure 2 plots the heat map of state-level total PPP loan amount (in dollars) received during the second round of PPP (April 27-August 9) scaled by the number of establishments with less than 500 employees in 2018. Panel C of Figure 2 plots the heat map of the share of bank branches owned by small banks (with less than $\$ 10$ billion in assets) in 2019.

\section{Figure 2, Panel A:}

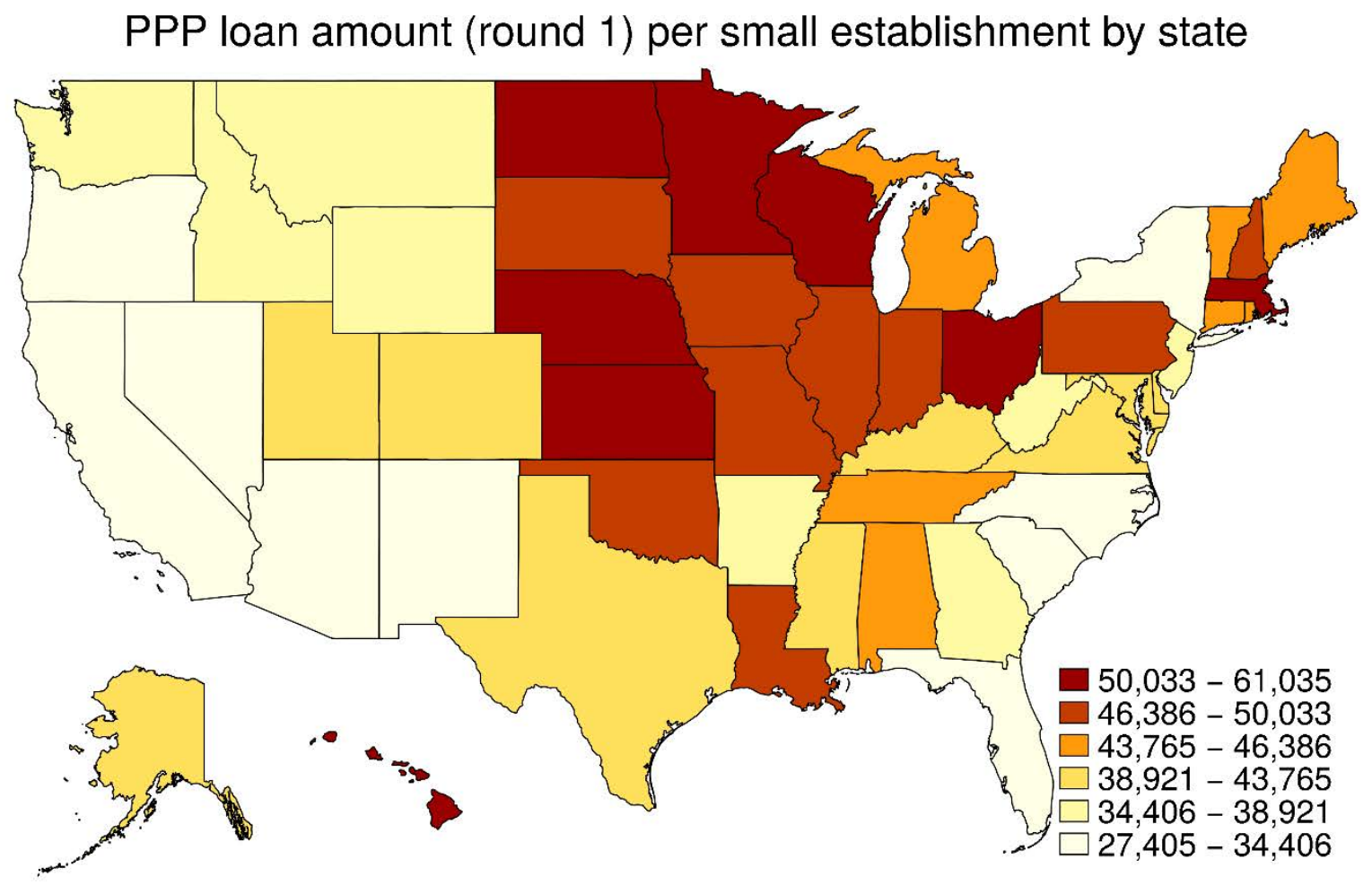


Figure 2, Panel B

PPP loan amount (round 2) per small establishment by state

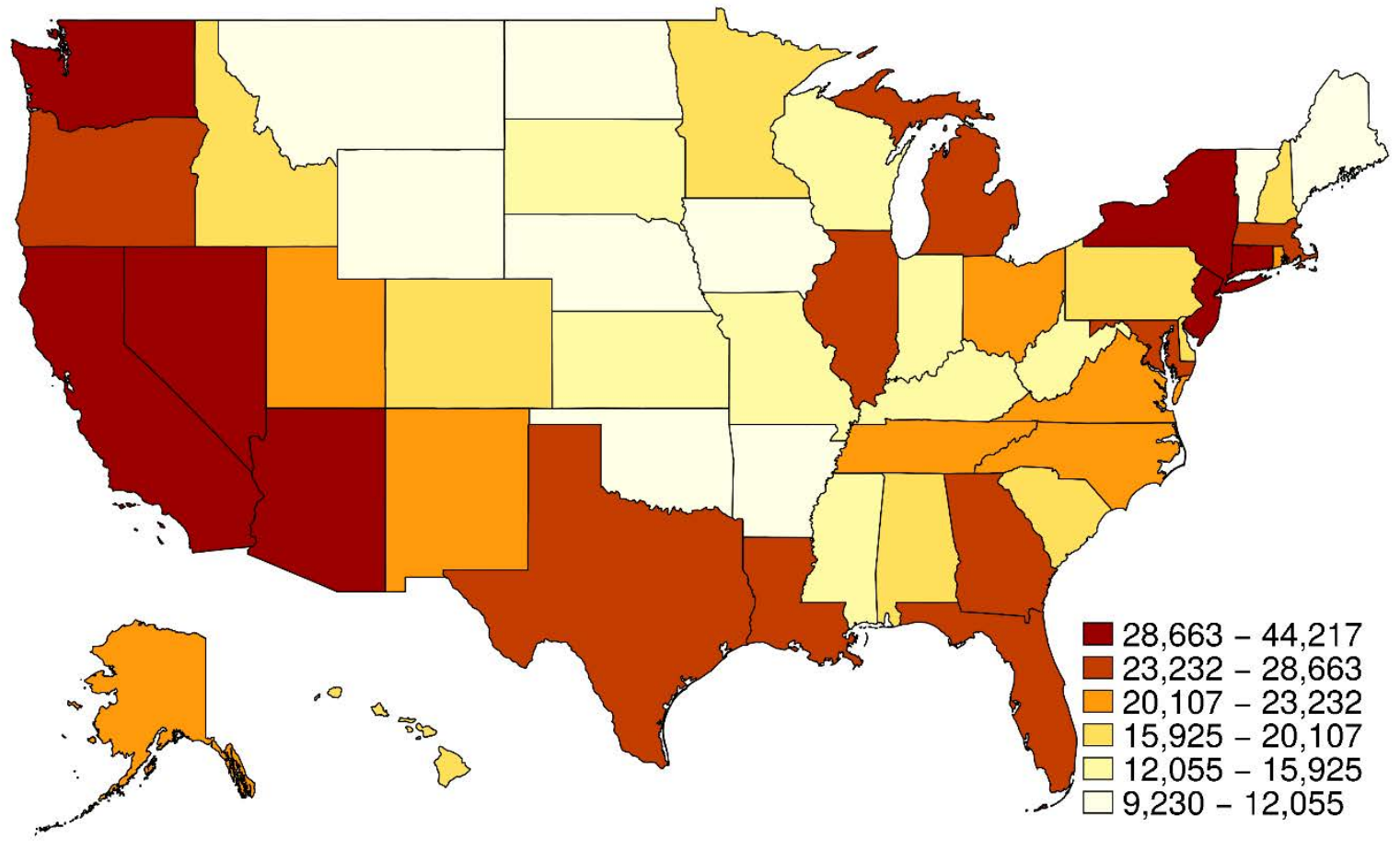


Figure 2, Panel C

Share of small bank branches by state

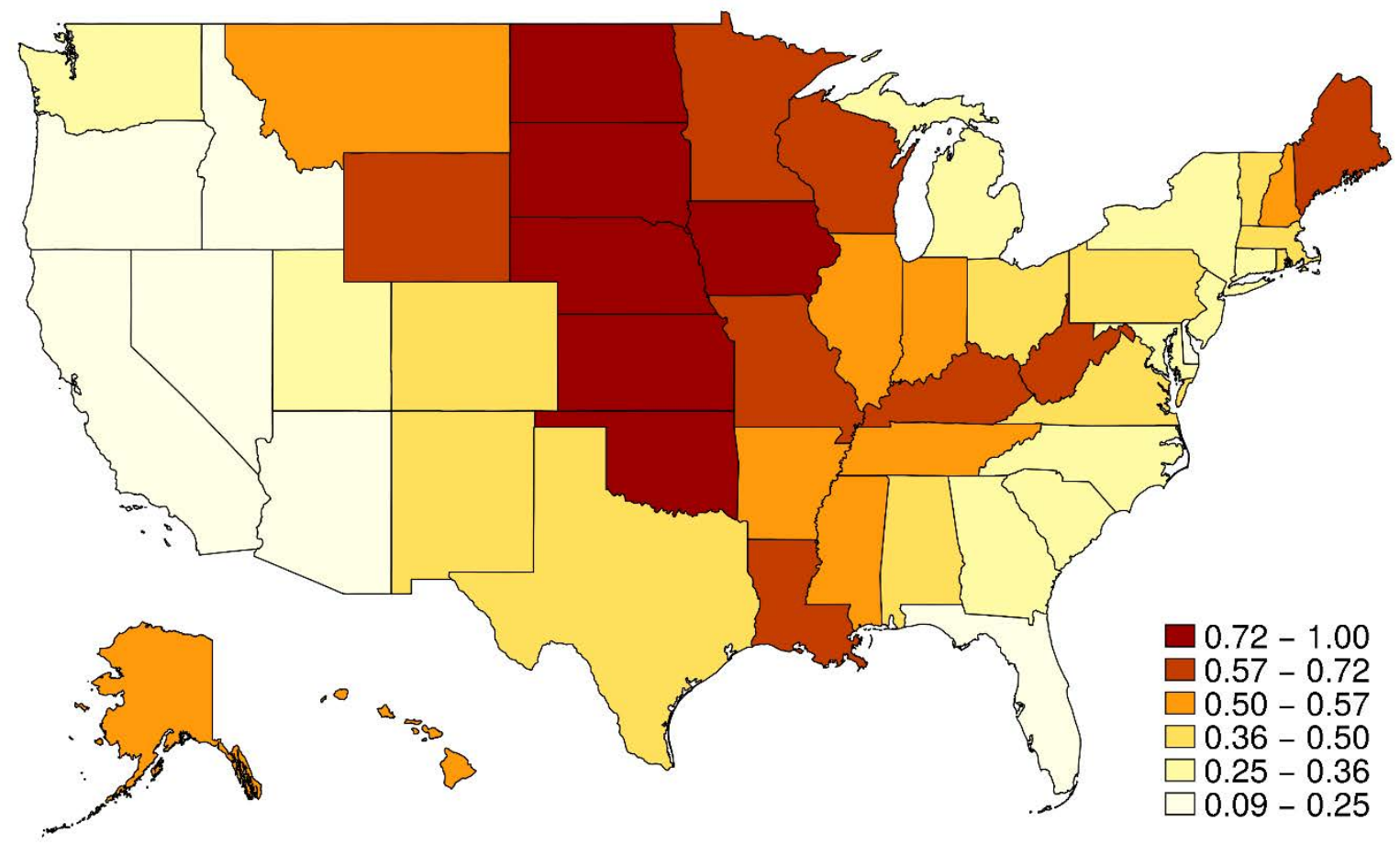




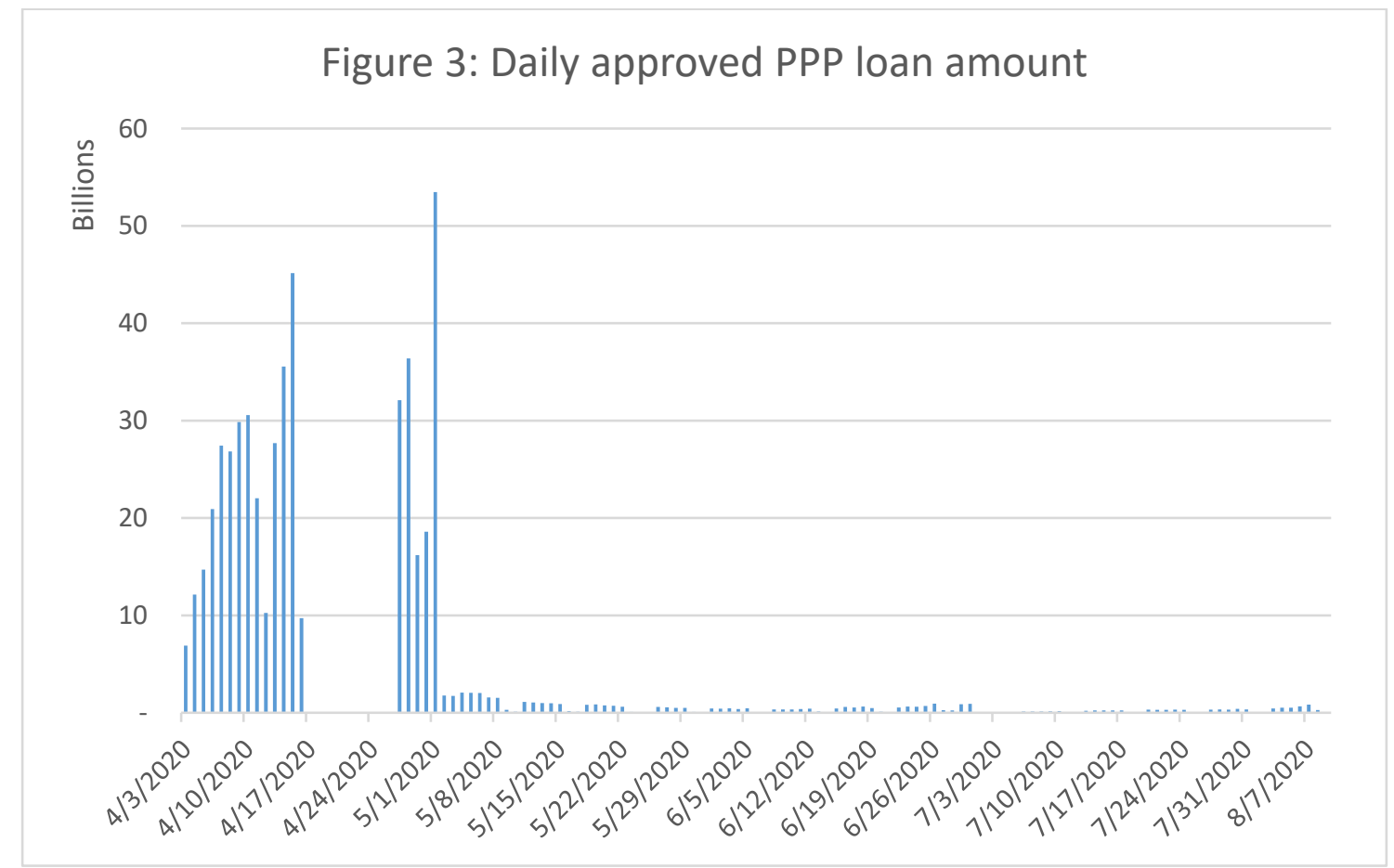

This figure plots the daily approved PPP loan amount. The data come from the Small Business Administration's (SBA) PPP loan level dataset. 


\section{Table 1: Summary Statistics for Bank Characteristics}

This table reports summary statistics for bank C\&I lending and PPP lending, along with other balance sheet characteristics, from Call Reports. The changes in lending are normalized by Q4, 2019 assets. C\&I credit equals the sum of C\&I loans on balance sheet plus unused C\&I commitments. Core markets are counties in which the bank owns at least one branch and peripheral markets are the other counties. log(Deposit-weighted average branch age) is derived from the 2019 Summary of Deposits data. Deposit-weighted COVID death rate is derived from county-level COVID death rates, which are the number of COVID deaths per 100,000 people, within a bank's branch network. All other variables come from the pre-COVID period (Q4, 2019) Call Reports. All variables, except log(Assets), are winsorized at the 1st and 99th percentiles.

\begin{tabular}{|c|c|c|c|c|c|c|}
\hline \multicolumn{7}{|l|}{ Panel A: 2020 Lending } \\
\hline $\mathrm{Q} 1$ & $\mathrm{~N}$ & mean & $\mathrm{sd}$ & p25 & p50 & p75 \\
\hline Change C\&I loans/Assets & 5,031 & 0.002 & 0.012 & -0.002 & 0.001 & 0.005 \\
\hline Change C\&I credit/Assets & 5,031 & 0.003 & 0.014 & -0.002 & 0.001 & 0.006 \\
\hline \multicolumn{7}{|l|}{ Q2 } \\
\hline Change C\&I loans/Assets & 4,980 & 0.054 & 0.067 & 0.012 & 0.037 & 0.070 \\
\hline Change C\&I credit/Assets & 4,980 & 0.058 & 0.070 & 0.014 & 0.040 & 0.076 \\
\hline Change non-PPP C\&I loans/Assets & 4,980 & -0.002 & 0.016 & -0.009 & -0.002 & 0.002 \\
\hline PPP loans/Assets & 4,980 & 0.057 & 0.069 & 0.013 & 0.040 & 0.076 \\
\hline \multicolumn{7}{|l|}{ Banks Matched to SBL Data } \\
\hline PPP loan in Core Markets/Assets & 4,333 & 0.034 & 0.037 & 0.006 & 0.023 & 0.049 \\
\hline PPP loan in Peripheral Markets/Assets & 4,333 & 0.031 & 0.058 & 0.003 & 0.012 & 0.030 \\
\hline
\end{tabular}

Panel B: PPP Loans/Assets, by Bank Size

Large ( $>\$ 50$ billion)

Medium ( $\$ 10$ to $\$ 50$ billion)

Small (Less than $\$ 10$ billion)

$\begin{array}{cc}\mathrm{N} & \mathrm{m} \\ 43 & 0 . \\ 90 & 0 . \\ 4,847 & 0 .\end{array}$

mean 0.021

$0.055 \quad 0.050$

sd $\quad \mathrm{p} 25$

$0.023 \quad 0.002$

0.058

0.069

0.002
0.025
0.013

p50

p75

0.034

Panel C: Bank 2019 Characteristics (for the Q2, 2020 sample)

\begin{tabular}{|c|c|c|c|c|c|c|}
\hline & $\mathrm{N}$ & mean & sd & p25 & p50 & p75 \\
\hline Unused C\&I Commitments/Assets & 4,980 & 0.031 & 0.035 & 0.007 & 0.021 & 0.043 \\
\hline Small C\&I Loans/Assets & 4,980 & 0.047 & 0.037 & 0.021 & 0.041 & 0.065 \\
\hline Core Deposits/Assets & 4,980 & 0.780 & 0.074 & 0.741 & 0.791 & 0.834 \\
\hline C\&I loans/Assets & 4,980 & 0.083 & 0.065 & 0.040 & 0.069 & 0.111 \\
\hline Liquid Assets/Assets & 4,980 & 0.295 & 0.157 & 0.178 & 0.256 & 0.381 \\
\hline Tier 1 Leverage Ratio & 4,980 & 0.118 & 0.035 & 0.097 & 0.109 & 0.128 \\
\hline $\log$ (Assets) & 4,980 & 12.565 & 1.468 & 11.614 & 12.377 & 13.260 \\
\hline log(Deposit-weighted average branch age) & 4,980 & 3.990 & 0.676 & 3.612 & 4.152 & 4.511 \\
\hline Deposit-weighted COVID death rate & 4,980 & 23.580 & 34.052 & 2.854 & 9.400 & 27.762 \\
\hline
\end{tabular}


Table 2 Summary Statistics for County-Level Economic Outcomes

This table reports summary statistics for the data used in the county-time panel regressions of real economic outcomes on measures of PPP credit. Small Business Revenue and

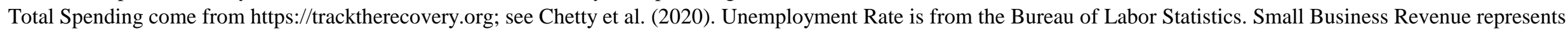
the percent change in net revenue, calculated each week day as a seven-day moving average (seasonally adjusted), indexed to January 4-31, 2020. Total Spending is the seasonally adjusted credit/debit card spending relative to January 4-31 2020. Unemployment Rate is by calendar month.

\begin{tabular}{|c|c|c|c|c|c|c|c|}
\hline \multirow[b]{3}{*}{ Time Period } & \multirow[b]{3}{*}{ Description } & \multicolumn{2}{|c|}{ Small Business Revenue } & \multicolumn{2}{|c|}{ Total Spending } & \multicolumn{2}{|c|}{ Unemployment Rate } \\
\hline & & & Standard & & Standard & & Standard \\
\hline & & Mean & Deviation & Mean & Deviation & Mean & Deviation \\
\hline $1 / 1 / 2020-2 / 15 / 2020$ & COVID affects Asia & 0.028 & 0.162 & 0.002 & 0.078 & 4.635 & 1.975 \\
\hline Pre-COVID (2/16/2020 - 3/10/2020) & COVID affects Western Europe & 0.054 & 0.192 & 0.007 & 0.105 & 4.356 & 1.895 \\
\hline Crisis (3/11/2020 - 4/3/2020) & Global Pandemic declared; Financial Market turmoil & -0.150 & 0.269 & -0.155 & 0.163 & 4.811 & 2.048 \\
\hline April (4/4/2020-4/30/2020) & Beginning of PPP Program & -0.229 & 0.289 & -0.241 & 0.130 & 12.450 & 5.238 \\
\hline May & Continuation of PPP Program & -0.061 & 0.304 & -0.125 & 0.138 & 10.348 & 4.117 \\
\hline June & Continuation of PPP Program & -0.028 & 0.294 & -0.066 & 0.137 & 8.455 & 3.312 \\
\hline July & Continuation of PPP Program & -0.061 & 0.304 & -0.050 & 0.124 & 7.878 & 3.082 \\
\hline August & PPP Program closed to new applications on August 8 & 020 & & & & & \\
\hline
\end{tabular}


Table 3: Bank Business Lending in the First Two Quarters of 2020

This table reports regressions of bank C\&I lending in the first two quarters of 2020 on pre-COVID balance sheet characteristics, from Call Reports. The changes in lending are normalized by Q4, 2019 assets. C\&I credit equals the sum of C\&I loans on balance sheet plus unused C\&I commitments. log(Deposit-weighted average branch age) is derived from the 2019 Summary of Deposits data. Deposit-weighted COVID death rate is derived from county-level COVID death rates within a bank's branch network. All other variables come from the preCOVID period (Q4, 2019) Call Reports. Stardard errors are clustered by bank headquarter state. T-statistics are reported in parentheses. '*' denotes significance at the $10 \%$ level, '**' the $5 \%$ level, and '***' the $1 \%$ level.

\begin{tabular}{|c|c|c|c|c|}
\hline & \multicolumn{2}{|c|}{$\mathrm{Q} 1,2020$} & \multicolumn{2}{|c|}{ Q2, 2020} \\
\hline & $\begin{array}{l}\text { Change C\&I } \\
\text { loans/Assets }\end{array}$ & $\begin{array}{l}\text { Change C\&I } \\
\text { credit/Assets }\end{array}$ & $\begin{array}{l}\text { Change C\&I } \\
\text { loans/Assets }\end{array}$ & $\begin{array}{l}\text { Change C\&I } \\
\text { credit/Assets }\end{array}$ \\
\hline & $(1)$ & $(2)$ & $(3)$ & $(4)$ \\
\hline \multicolumn{5}{|l|}{ Relationship Measures } \\
\hline Unused C\&I comm./Assets & $\begin{array}{c}0.0600^{* * * *} \\
(7.120)\end{array}$ & $\begin{array}{c}0.00572 \\
(0.452)\end{array}$ & $\begin{array}{c}0.423^{* * *} \\
(7.217)\end{array}$ & $\begin{array}{c}0.507 * * * \\
(7.956)\end{array}$ \\
\hline Small C\&I loans/Assets & $\begin{array}{l}-0.0117 \\
(1.019)\end{array}$ & $\begin{array}{c}6.36 \mathrm{e}-05 \\
(0.00522)\end{array}$ & $\begin{array}{l}0.131 * * \\
(2.094)\end{array}$ & $\begin{array}{l}0.111^{*} \\
(1.696)\end{array}$ \\
\hline Core deposits/Assets & $\begin{array}{c}0.00261 \\
(1.172)\end{array}$ & $\begin{array}{c}0.00390 \\
(1.521)\end{array}$ & $\begin{array}{c}0.0763^{* * *} \\
(4.310)\end{array}$ & $\begin{array}{c}0.0836 * * * \\
(4.628)\end{array}$ \\
\hline \multicolumn{5}{|l|}{ Other Balance Sheet Ratios } \\
\hline C\&I loans/Assets & $\begin{array}{c}0.0179 * * \\
(2.149)\end{array}$ & $\begin{array}{c}0.0230 * * \\
(2.389)\end{array}$ & $\begin{array}{l}0.0505 \\
(1.116)\end{array}$ & $\begin{array}{c}0.0790 * \\
(1.684)\end{array}$ \\
\hline Liquid assets/Assets & $\begin{array}{c}-2.38 \mathrm{e}-05 \\
(0.0173)\end{array}$ & $\begin{array}{c}-0.00141 \\
(0.912)\end{array}$ & $\begin{array}{c}-0.0315^{* * *} \\
(4.388)\end{array}$ & $\begin{array}{c}-0.0331^{* * *} \\
(4.514)\end{array}$ \\
\hline Tier 1 leverage ratio & $\begin{array}{c}0.0256^{* *} \\
(2.402)\end{array}$ & $\begin{array}{c}0.0296 * * \\
(2.357)\end{array}$ & $\begin{array}{l}0.0470 \\
(0.982)\end{array}$ & $\begin{array}{l}0.0553 \\
(1.070)\end{array}$ \\
\hline \multicolumn{5}{|l|}{ Other Control Variables } \\
\hline $\log$ (Assets) & $\begin{array}{c}0.000402^{* *} \\
(2.559)\end{array}$ & $\begin{array}{c}0.000192 \\
(1.326)\end{array}$ & $\begin{array}{c}-0.00436 * * * \\
(3.973)\end{array}$ & $\begin{array}{c}-0.00409 * * * \\
(3.695)\end{array}$ \\
\hline log(Deposit-weighted average branch age) & $\begin{array}{c}-0.000371 \\
(1.112)\end{array}$ & $\begin{array}{c}-0.000612 \\
(1.281)\end{array}$ & $\begin{array}{c}-0.0317^{* * *} \\
(10.06)\end{array}$ & $\begin{array}{c}-0.0324^{* * *} \\
(10.20)\end{array}$ \\
\hline Deposit-weighted COVID death rate & $\begin{array}{c}9.73 e-05^{*} \\
(1.684)\end{array}$ & $\begin{array}{c}2.23 e-05 \\
(0.462)\end{array}$ & $\begin{array}{c}3.51 \mathrm{e}-05 \\
(1.002)\end{array}$ & $\begin{array}{c}3.42 \mathrm{e}-05 \\
(0.987)\end{array}$ \\
\hline Constant & $\begin{array}{c}-0.00917^{* * *} \\
(2.865)\end{array}$ & $\begin{array}{c}-0.00567 \\
(1.460) \\
\end{array}$ & $\begin{array}{c}0.154^{* * * *} \\
(7.298) \\
\end{array}$ & $\begin{array}{c}0.148^{* * *} \\
(6.900) \\
\end{array}$ \\
\hline Observations & 5,031 & 5,031 & 4,980 & 4,980 \\
\hline R-squared & 0.074 & 0.020 & 0.235 & 0.264 \\
\hline
\end{tabular}


Table 4: Bank Lending in the Second Quarter of 2020, PPP v. non-PPP C\&I Lending

This table reports regressions comparing bank non-PPP C\&I lending v. PPP lending in the second quarter of 2020 on pre-COVID balance sheet characteristics, from Call Reports. The changes in lending are normalized by Q4, 2019 assets. C\&I credit equals the sum of C\&I loans on balance sheet plus unused C\&I commitments.

$\log$ (Deposit-weighted average branch age) is derived from the 2019 Summary of Deposits data. Deposit-weighted COVID death rate is derived from county-level COVID death rates within a bank's branch network. All other variables come from the pre-COVID period (Q4, 2019) Call Reports. Stardard errors are clustered by bank headquarter state. T-statistics are reported in parentheses. '*' denotes significance at the $10 \%$ level, '**' the $5 \%$ level, and '***' the $1 \%$ level.

\begin{tabular}{|c|c|c|c|}
\hline & $\begin{array}{l}\text { Change non-PPP } \\
\text { C\&I loans/Assets }\end{array}$ & $\begin{array}{c}\text { Change non-PPP C\&I } \\
\text { credit/Assets }\end{array}$ & PPP loans/Assets \\
\hline & (1) & (2) & (3) \\
\hline \multicolumn{4}{|l|}{ Relationship Measures } \\
\hline Unused C\&I comm./Assets & $\begin{array}{c}-0.0778^{* * *} \\
(8.225)\end{array}$ & $\begin{array}{l}0.000111 \\
(0.00721)\end{array}$ & $\begin{array}{c}0.494 * * * \\
(7.912)\end{array}$ \\
\hline Small C\&I loans/Assets & $\begin{array}{c}0.00303 \\
(0.219)\end{array}$ & $\begin{array}{l}-0.0140 \\
(1.024)\end{array}$ & $\begin{array}{c}0.127^{* *} \\
(2.168)\end{array}$ \\
\hline Core deposits/Assets & $\begin{array}{c}-0.00412 \\
(1.502)\end{array}$ & $\begin{array}{l}0.00148 \\
(0.526)\end{array}$ & $\begin{array}{c}0.0809^{* * *} \\
(4.514)\end{array}$ \\
\hline \multicolumn{4}{|l|}{ Other Balance Sheet Ratios } \\
\hline C\&I loans/Assets & $\begin{array}{l}-0.0229 * * * \\
\quad(3.616)\end{array}$ & $\begin{array}{c}0.00507 \\
(0.700)\end{array}$ & $\begin{array}{l}0.0716 \\
(1.573)\end{array}$ \\
\hline Liquid assets/Assets & $\begin{array}{c}-0.000192 \\
(0.132)\end{array}$ & $\begin{array}{c}-0.00117 \\
(0.936)\end{array}$ & $\begin{array}{c}-0.0320^{* * * *} \\
(4.146)\end{array}$ \\
\hline Tier 1 leverage ratio & $\begin{array}{l}0.00222 \\
(0.375)\end{array}$ & $\begin{array}{c}0.00878 \\
(1.016)\end{array}$ & $\begin{array}{l}0.0427 \\
(0.897)\end{array}$ \\
\hline \multicolumn{4}{|l|}{ Other Control Variables } \\
\hline $\log$ (Assets) & $\begin{array}{c}-0.00108^{* * *} \\
(5.601)\end{array}$ & $\begin{array}{c}-0.000728^{* * * *} \\
(3.516)\end{array}$ & $\begin{array}{c}-0.00309^{* * *} \\
(2.685)\end{array}$ \\
\hline log(Deposit-weighted average branch age) & $\begin{array}{c}-0.000574^{*} \\
(1.851)\end{array}$ & $\begin{array}{c}-0.00128^{* * * *} \\
(3.136)\end{array}$ & $\begin{array}{c}-0.0307^{* * * *} \\
(9.094)\end{array}$ \\
\hline Deposit-weighted COVID death rate & $\begin{array}{c}8.33 \mathrm{e}-06 \\
(1.594)\end{array}$ & $\begin{array}{c}6.15 \mathrm{e}-06 \\
(1.006)\end{array}$ & $\begin{array}{c}2.36 \mathrm{e}-05 \\
(0.659)\end{array}$ \\
\hline Constant & $\begin{array}{c}0.0188 * * * \\
(4.736) \\
\end{array}$ & $\begin{array}{c}0.0125^{* * *} \\
(2.699) \\
\end{array}$ & $\begin{array}{c}0.132 * * * \\
(5.782) \\
\end{array}$ \\
\hline Observations & 4,980 & 4,980 & 4,980 \\
\hline R-squared & 0.123 & 0.006 & 0.262 \\
\hline
\end{tabular}




\section{Table 5: Bank PPP Lending, by Size}

This table reports regressions of bank PPP lending, normalized by Q4, 2019 assets, in the second quarter of 2020 on pre-COVID balance sheet characteristics, from Call Reports. Large, medium-sized, and small banks are those with $>\$ 50$ billion, $10-50$ billion, and $<\$ 10$ billions in assets, respectively. $\log$ (Deposit-weighted average branch age) is derived from the 2019 Summary of Depositsdata. Deposit-weighted COVID death rate is derived from county-level COVID death rates within a bank's branch network. All other variables come from the pre-COVID period (Q4, 2019) Call Report. Stardard errors are clustered by bank headquarter state. T-statistics are reported in parentheses. '*' denotes significance at the $10 \%$ level, '**' the $5 \%$ level, and '***' the $1 \%$ level.

\begin{tabular}{lccc}
\hline & Large Banks & Medium Sized Banks & Small Banks \\
\cline { 2 - 4 } Relationship Measures & $(1)$ & $(2)$ & $(3)$ \\
Unused C\&I comm./Assets & 0.0466 & $0.601^{* * *}$ & $0.516^{* * *}$ \\
Small C\&I loans/Assets & $(0.876)$ & $(3.914)$ & $(7.965)$ \\
Core deposits/Assets & -0.0549 & $0.570^{* * *}$ & $0.119^{* *}$ \\
& $(1.037)$ & $(2.722)$ & $(2.077)$ \\
Other Balance Sheet Ratios & $0.0437^{*}$ & 0.0319 & $0.0815^{* * *}$ \\
\hline C\&I loans/Assets & $(1.884)$ & $(0.678)$ & $(4.429)$ \\
& & & \\
Liquid assets/Assets & $0.104^{* *}$ & $-0.212^{* * *}$ & $0.0827^{*}$ \\
& $(2.628)$ & $(2.919)$ & $(1.761)$ \\
Tier 1 leverage ratio & $-0.0391^{* *}$ & $-0.0591^{*}$ & $-0.0246^{* * *}$ \\
& $(2.488)$ & $(1.745)$ & $(3.103)$ \\
Other Control Variables & $-0.359^{*}$ & -0.0998 & 0.0514 \\
log(Assets) & $(2.101)$ & $(0.495)$ & $(1.023)$ \\
& & & \\
log(Deposit-weighted average branch age) & $-0.00736^{* *}$ & $-0.0320^{* *}$ & 0.000215 \\
& $(2.530)$ & $(2.254)$ & $(0.163)$ \\
Deposit-weighted COVID death rate & 0.00598 & -0.0204 & $-0.0293^{* * *}$ \\
Constant & $(1.053)$ & $(1.076)$ & $(8.377)$ \\
& $-3.88 \mathrm{e}-05$ & 0.000163 & $1.73 \mathrm{e}-05$ \\
& $(1.260)$ & $(0.796)$ & $(0.494)$ \\
Observations & $0.137 * *$ & $0.633^{*}$ & $0.0813^{* * *}$ \\
R-squared & $(2.820)$ & $(1.907)$ & $(3.173)$ \\
\hline & & & \\
& 43 & 90 & 0.274 \\
\hline
\end{tabular}


Table 6: Bank PPP Lending, Relationship Measures in Core v. Peripheral Markets

This table reports regressions of bank PPP lending on pre-COVID balance sheet characteristics, separated into markets with and without bank branches. PPP lending data are taken from the Small Business

Administration, and bank characteristics are from Call Reports. Core Markets are counties in which the bank owns at least one branch; Peripheral Markets are counties in which the bank owns no branches. Branch locations are determined from the 2019 Summary of Deposits data. The dependent variables are PPP lending in core and peripheral markets, normalized by Q4, 2019 assets, and their difference. Round 1 PPP

lendings include PPP loans approved before April 17 and Round 2 include loans approved after April 17. Large, medium-sized, and small banks are those with >\$50 billion, $10-50$ billion, and $<\$ 10$ billions in assets,

respectively. Regressions include (but don't report) the other control variables from Tables 3-5. Stardard errors are clustered by bank headquarter state. T-statistics are reported in parentheses. '*' denotes significance at the $10 \%$ level, '**' the $5 \%$ level, and '***' the $1 \%$ level.

\section{Panel A: All PPP}

Unused C\&I comm./Assets

\begin{tabular}{ccccc}
$(1)$ & $(2)$ & $(3)$ & $(4)$ & $(5)$ \\
\hline & All banks & & \multicolumn{3}{c}{ Large banks } \\
\hline \multirow{3}{*}{ Core Markets } & Peripheral & & Core & Peripheral \\
& Markets & Difference & Markets & Markets
\end{tabular}

(6)

$$
\text { (7) }
$$

$\begin{array}{cc} & (8) \\ \text { Mid-sized banks } \\ \text { Peripheral } \\ \text { Markets }\end{array}$

$\begin{array}{ccccc}\text { Core Markets } & \text { Markets } & \text { Difference } & \text { Markets } & \text { Mar } \\ 0.367^{* * *} & 0.147^{* * *} & 0.221^{* * *} & 0.0227 & -0.0 \\ (9.696) & (3.494) & (3.935) & (0.337) & (0.8\end{array}$

$\begin{array}{cccc}(9.696) & (3.494) & (3.935) & (0.337) \\ 0.143 * * * & 0.0289 & 0.115 * * & -0.0806\end{array}$

$\begin{array}{llll}(3.978) & (0.696) & (2.484) & (1.065)\end{array}$

\begin{tabular}{llll}
$0.0604^{* * *}$ & 0.00386 & $0.0566^{* * *}$ & 0.0626 \\
\hline
\end{tabular}

Core deposits/Assets

\begin{tabular}{cccc}
$(6.351)$ & $(0.259)$ & $(4.127)$ & $(1.644)$ \\
\hline
\end{tabular}

Observations

R-squared

\begin{tabular}{cccccccccccc}
$(6.351)$ & $(0.259)$ & $(4.127)$ & $(1.644)$ & $(0.494)$ & $(1.744)$ & $(0.732)$ & $(0.316)$ & $(0.836)$ & $(6.360)$ & $(0.291)$ & $(3.810)$ \\
\hline & & & & & & & & & & & \\
4,333 & 4,333 & 4,333 & 40 & 40 & 40 & 81 & 81 & 81 & 4,212 & 4,212 & 4,212 \\
0.339 & 0.076 & 0.058 & 0.514 & 0.584 & 0.423 & 0.607 & 0.161 & 0.328 & 0.368 & 0.074 & 0.061 \\
\hline
\end{tabular}

Panel B: First Round

Unused C\&I comm./Assets

\begin{tabular}{|c|c|c|c|c|c|c|c|c|c|c|c|}
\hline \multicolumn{3}{|c|}{ All banks } & \multicolumn{3}{|c|}{ Large banks } & \multicolumn{3}{|c|}{ Mid-sized banks } & \multicolumn{3}{|c|}{ Small banks } \\
\hline & Peripheral & & Core & Peripheral & & & Peripheral & & & Peripheral & \\
\hline Core Markets & Markets & Difference & Markets & Markets & Difference & Core Markets & Markets & Difference & Core Markets & Markets & Difference \\
\hline $0.296 * * *$ & $0.121^{* * *}$ & $0.174 * * *$ & 0.0102 & -0.0133 & 0.0234 & $0.317 * * *$ & 0.0459 & $0.271^{* * *}$ & $0.312^{* * *}$ & $0.130^{* * *}$ & $0.181^{* * *}$ \\
\hline$(10.47)$ & (4.735) & (4.959) & $(0.191)$ & $(1.001)$ & $(0.488)$ & $(4.801)$ & (1.532) & (3.597) & (10.45) & (4.717) & (4.892) \\
\hline $0.114 * * *$ & $0.0495 * *$ & $0.0642^{* *}$ & -0.0397 & $-0.0389 *$ & -0.000766 & $0.428^{* * *}$ & 0.0853 & $0.342^{* *}$ & $0.118^{* * *}$ & 0.0423* & $0.0758^{* *}$ \\
\hline (3.864) & $(2.084)$ & $(2.082)$ & $(0.571)$ & $(1.984)$ & $(0.0122)$ & (2.896) & (1.201) & $(2.237)$ & (3.899) & (1.795) & $(2.291)$ \\
\hline $0.0459 * * *$ & -0.00107 & $0.0469 * * *$ & $0.0493 * *$ & 0.00195 & $0.0474 * *$ & 0.0190 & -0.00691 & 0.0259 & $0.0449 * * *$ & -0.000949 & $0.0459 * * *$ \\
\hline (5.617) & $(0.107)$ & $(5.464)$ & $(2.204)$ & $(0.486)$ & $(2.276)$ & $(0.796)$ & $(0.593)$ & $(1.212)$ & (5.622) & $(0.0922)$ & (5.197) \\
\hline
\end{tabular}

Small C\&I loans/Assets

Core deposits/Assets

$-0.0145$

$(0.835)$

$-0.0242$

0.0372

$(0.607)$

$\begin{array}{cc}\text { Core Markets } & \text { Markets } \\ 0.390^{* * *} & 0.145\end{array}$

(5.753)

$0.699 * * *$

(1.463)

0.0122

(0.0715)

$-0.00653$

(9)
Difference Core Markets $\begin{gathered}\text { Peripheral } \\ \text { Markets Difference }\end{gathered}$ $\begin{array}{cccc}0.245^{*} & 0.384^{* * *} & 0.157^{* * *} & 0.227^{* * *}\end{array}$ $\begin{array}{llll}(1.789) & \text { (9.665) (3.495) }\end{array}$ $\begin{array}{llll}0.687^{* *} & 0.149^{* * *} & 0.0163 & 0.133^{* * *}\end{array}$ $\begin{array}{lccc}(2.378) & (4.017) & (0.381) & (2.684) \\ 0.0288 & 0.0592^{* * *} & 0.00451 & 0.0547^{* * *}\end{array}$ $\begin{array}{cccc}0.0288 & 0.0592^{* * *} & 0.00451 & 0.0547^{* *} \\ (0.836) & (6.360) & (0.291) & (3.810)\end{array}$

\begin{tabular}{|c|c|c|c|c|c|c|c|c|c|c|c|c|}
\hline & $(5.617)$ & $(0.107)$ & $(5.464)$ & $(2.204)$ & $(0.486)$ & $(2.276)$ & $(0.796)$ & $(0.593)$ & $(1.212)$ & $(5.622)$ & $(0.0922)$ & $(5.197)$ \\
\hline Observations & 4,206 & 4,206 & 4,206 & 40 & 40 & 40 & 80 & 80 & 80 & 4,086 & 4,086 & 4,086 \\
\hline \multirow[t]{3}{*}{ R-squared } & 0.334 & 0.084 & 0.071 & 0.461 & 0.554 & 0.384 & 0.544 & 0.184 & 0.477 & 0.370 & 0.084 & 0.077 \\
\hline & \multicolumn{3}{|c|}{ All banks } & \multicolumn{3}{|c|}{ Large banks } & \multicolumn{3}{|c|}{ Mid-sized banks } & \multicolumn{3}{|c|}{ Small banks } \\
\hline & & Peripheral & & Core & Peripheral & & & Peripheral & & & Peripheral & \\
\hline Panel C: Second Round & Core Markets & Markets & Difference & Markets & Markets & Difference & Core Markets & Markets & Difference & Core Markets & Markets & Difference \\
\hline Unused C\&I comm./Assets & $\begin{array}{c}0.0608^{* * *} \\
(5.214)\end{array}$ & $\begin{array}{l}0.0201 \\
(1.329)\end{array}$ & $\begin{array}{c}0.0408 * * \\
(2.245)\end{array}$ & $\begin{array}{l}0.0129 \\
(0.417)\end{array}$ & $\begin{array}{c}-0.00119 \\
(0.175)\end{array}$ & $\begin{array}{l}0.0141 \\
(0.509)\end{array}$ & $\begin{array}{c}0.0693 * * \\
(2.055)\end{array}$ & $\begin{array}{l}0.0557 \\
(1.243)\end{array}$ & $\begin{array}{l}0.0136 \\
(0.217)\end{array}$ & $\begin{array}{c}0.0605^{* * *} \\
(5.017)\end{array}$ & $\begin{array}{l}0.0203 \\
(1.262)\end{array}$ & $\begin{array}{c}0.0402^{* *} \\
(2.149)\end{array}$ \\
\hline Small C\&I loans/Assets & $\begin{array}{c}0.0317^{* * * *} \\
(3.469)\end{array}$ & $\begin{array}{c}-0.00460 \\
(0.280)\end{array}$ & $\begin{array}{c}0.0363 * * \\
(2.386)\end{array}$ & $\begin{array}{c}-0.0403 \\
(0.771)\end{array}$ & $\begin{array}{l}0.0143 \\
(0.945)\end{array}$ & $\begin{array}{l}-0.0545 \\
(1.277)\end{array}$ & $\begin{array}{c}0.247 * * * \\
(2.804)\end{array}$ & $\begin{array}{l}-0.0197 \\
(0.258)\end{array}$ & $\begin{array}{c}0.267 * * \\
(2.064)\end{array}$ & $\begin{array}{c}0.0338 * * * \\
(3.657)\end{array}$ & $\begin{array}{c}-0.00909 \\
(0.531)\end{array}$ & $\begin{array}{c}0.0429 * * * \\
(2.715)\end{array}$ \\
\hline Core deposits/Assets & $\begin{array}{c}0.0162 * * * \\
(6.320) \\
\end{array}$ & $\begin{array}{c}0.00271 \\
(0.521) \\
\end{array}$ & $\begin{array}{c}0.0135^{* *} \\
(2.659) \\
\end{array}$ & $\begin{array}{l}0.0134 \\
(0.780) \\
\end{array}$ & $\begin{array}{c}0.00132 \\
(0.439) \\
\end{array}$ & $\begin{array}{l}0.0121 \\
(0.818) \\
\end{array}$ & $\begin{array}{c}0.00365 \\
(0.281) \\
\end{array}$ & $\begin{array}{c}-0.000912 \\
(0.0942) \\
\end{array}$ & $\begin{array}{c}0.00456 \\
(0.298) \\
\end{array}$ & $\begin{array}{c}0.0160^{* * *} \\
(6.349) \\
\end{array}$ & $\begin{array}{l}0.00315 \\
(0.578) \\
\end{array}$ & $\begin{array}{c}0.0129 * * \\
(2.423) \\
\end{array}$ \\
\hline Observations & 4,329 & 4,329 & 4,329 & 40 & 40 & 40 & 81 & 81 & 81 & 4,208 & 4,208 & 4,208 \\
\hline R-squared & 0.216 & 0.061 & 0.038 & 0.395 & 0.536 & 0.362 & 0.293 & 0.164 & 0.176 & 0.227 & 0.059 & 0.038 \\
\hline
\end{tabular}




\section{Table 7: PPP Lending, Within-Bank Tests}

This table reports bank-county level regressions of PPP lending on bank-county characteristics. The dependent variable is log(1+PPP lending amount) by the bank in the county. We include all banks merged to the SBA PPP data, plus all banks identified as having zero PPP lending from the bank Call Reports. For each bank, we inlude all counties in which the bank owns at least one branch. Deposit characteristics are taken from the 2019 Summary of Deposits. CRA characteristics are taken from the 2018 CRA data. Regressions with CRA data include only banks with assets over $\$ 1$ billion. Large, medium-sized, and small banks are those with $>\$ 50$ billion, $10-50$ billion, and $<\$ 10$ billions in assets, respectively. Stardard errors are clustered by bank and county. T-statistics are reported in parentheses. '*' denotes significance at the $10 \%$ level, '**' the $5 \%$ level, and '***' the $1 \%$ level.

\%Bank Deposits from the county

$\log$ (deposit-weighted average branch age)

All banks

Large banks

(3) (4)

(1) (2)

$0.574 * * * \quad 0.0753$

0.0753

(5.933)

(0.478)

$0.0876^{* * *}$

$0.172 * * *$

(4.110)

$5.796 * * *$

(5.200)

\%County Deposits held by the bank

\%Bank CRA Loans from the county

\%County CRA Loans held by the bank

$3.888 * * *$

(11.48)

$3.832 * *$

(2.451)

$3.976 * * *$

$-1.106$

(0.906)

$0.245^{* * *}$

(4.599)

$5.271^{* * *}$

(11.23)
(10.23)

$-1.534$

$-1.534 *$

(2.019)

$0.242^{* * *}$

(5.266)

$3.343 * * *$

(6.683)

6.798

(1.236)

4.264***

(8.947)

\begin{tabular}{cccc} 
& $\begin{array}{c}3.976^{* * *} \\
(10.23)\end{array}$ & & $\begin{array}{c}4.264^{* * *} \\
(8.947)\end{array}$ \\
\hline & & & \\
22,830 & 13,342 & 4,922 & 4,922 \\
0.966 & 0.954 & 0.932 & 0.935 \\
YES & YES & YES & YES \\
YES & YES & YES & YES
\end{tabular}

Observations

R-squared

Bank FEs

County FEs
(0.173)

$0.110^{* *}$

(2.542)

$5.762 * * *$

(9.682)

0.935

YES

YES
Mid-sized banks

(5)

$-0.0706$

(6)

$-0.314$

(0.662)

$0.0926 * *$

(2.281)

$3.313^{* * *}$

(5.905)

$5.385 * * *$

(3.099)

$3.500 * * *$

(5.952)

2,618
0.985
YES
YES

2,593

0.985

YES

YES
Small banks

(7) (8)

$0.801^{* * *} \quad 0.0184$

(5.226) (0.0605)

$0.0510^{* *} \quad 0.152^{* *}$

(2.120) (2.326)

$5.032 * * * \quad 6.394 * * *$

(7.353) (4.699)

$8.864^{* * *}$

(3.077)

1.386*

(1.651)

(1.651)

3,882

3,882

0.961

YES

YES




\section{Table 8: County Level PPP Lending}

This table reports county level regressions of PPP lending on county-level banking characteristics and demographics. The dependent variable is county-level PPP lending scaled by the number of establishments with fewer than 500 employees. Total PPP lending includes all PPP loans in the SBA data; the division into core v. peripheral lenders includes only loans which we were able to match to Call Reports lenders (about $94.8 \%$ of the total). Core lenders are banks that have at least one branch in the county and peripheral lenders are those witout branch in the county. Round 1 PPP lendings include PPP loans approved before April 17 and Round 2 include loans approved after April 17. Branches/Establishment is the ratio of total branches / establishments with fewer than 500 employees as of 2019. Predicted PPP Lending equals the weighted average of each bank's predicted bank-level PPP Lending/Assets in their core markets, with weights equal to each bank's share of total deposits in the county from 2019. Stardard errors are clustered by state. T-statistics are reported in parentheses. '*' denotes significance at the $10 \%$ level, '**' the $5 \%$ level, and '***' the $1 \%$ level.

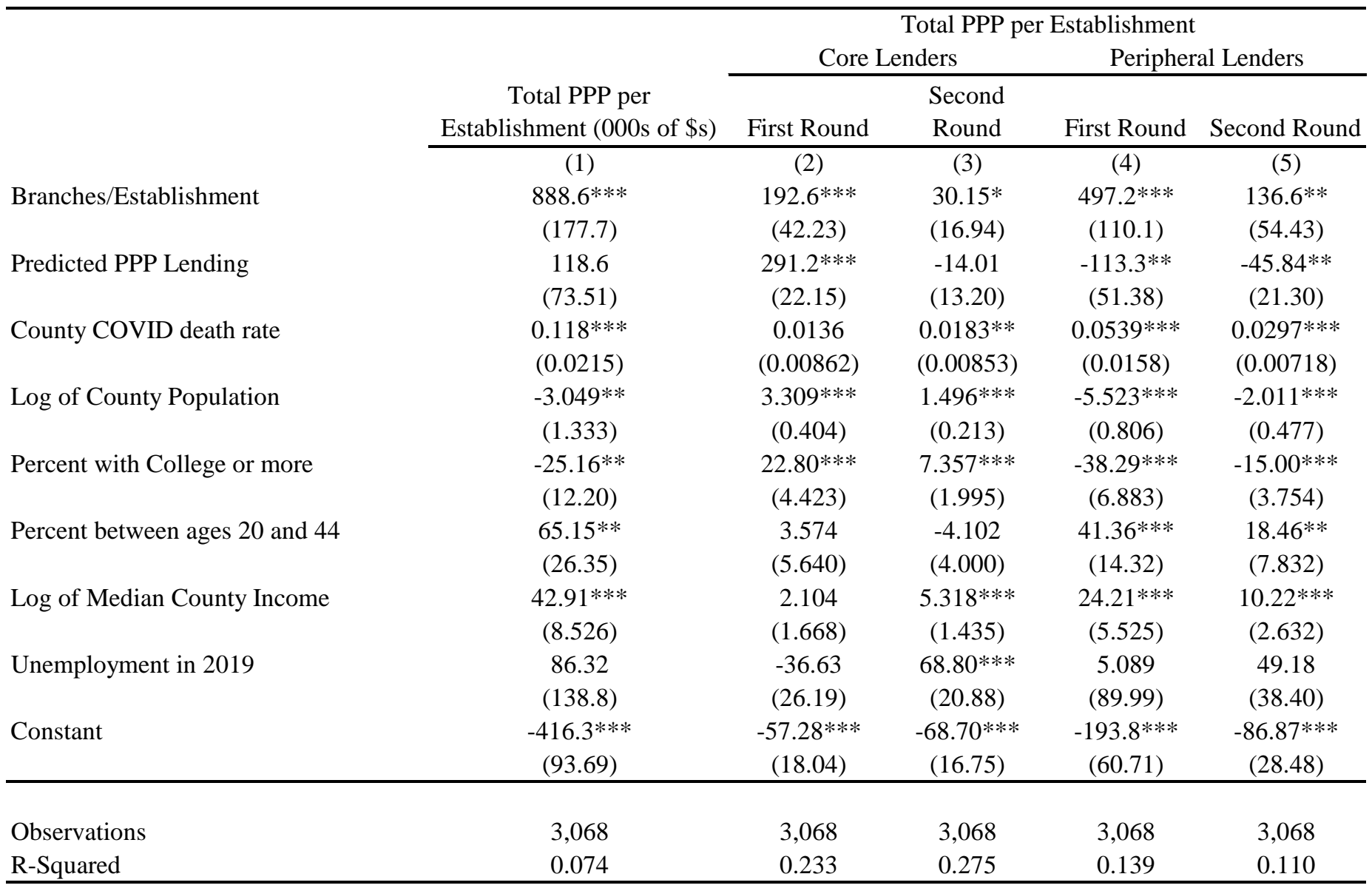


Table 9 County-Level Economic Outcomes and PPP Lending by Local Banks

This table reports county-time panel regressions of real economic outcomes on measures of the size and structure of local banks. Small Business Revenue and Total Spending come from https://tracktherecovery.org; see Chetty et al. (2020). Monthly unemployment rates by county are from the Bureau of Labor Statistics. Predicted PPP Lending equals the weighted average of each bank's predicted bank-level PPP Lending/Assets in their core markets, with weights equal to each bank's share of total deposits in the county from 2019. Stardard errors are clustered by county and time in columns (1) and (2) and by count and state-time in column (3). T-statistics are reported in parentheses. '*' denotes significance at the $10 \%$ level, '**' the $5 \%$ level, and '***' the $1 \%$ level. F-statistic tests that the Predicted PPP lending, times the four time interactions from April on, equal zero.

\begin{tabular}{|c|c|c|c|}
\hline \multicolumn{4}{|c|}{ Small Business } \\
\hline & Revenue & Total Spending & Unemployment Rate \\
\hline & (1) & (2) & (3) \\
\hline \multirow[t]{2}{*}{ March x Predicted PPP Lending } & 0.415 & $0.267^{*}$ & -0.618 \\
\hline & $(0.331)$ & $(0.158)$ & $(1.147)$ \\
\hline \multirow{2}{*}{ April x Predicted PPP Lending } & 0.179 & 0.258 & 1.837 \\
\hline & $(0.472)$ & $(0.230)$ & $(5.105)$ \\
\hline \multirow[t]{2}{*}{ May x Predicted PPP Lending } & 0.525 & 0.398 & $-10.71^{* * *}$ \\
\hline & $(0.502)$ & $(0.264)$ & $(3.946)$ \\
\hline \multirow[t]{2}{*}{ June x Predicted PPP Lending } & 0.577 & 0.0783 & $-15.19 * * *$ \\
\hline & $(0.522)$ & $(0.301)$ & (3.608) \\
\hline \multirow[t]{2}{*}{ July x Predicted PPP Lending } & 0.223 & 0.0578 & $-15.04 * * *$ \\
\hline & $(0.535)$ & $(0.262)$ & $(3.537)$ \\
\hline F-Test & 0.78 & 1.08 & 8.13 \\
\hline P-value & 0.540 & 0.370 & 0.001 \\
\hline County Fixed Effects & YES & YES & YES \\
\hline State $\mathrm{x}$ Time effects & YES & YES & YES \\
\hline Frequency & Daily & Daily & Monthly \\
\hline Control Variables: & \multicolumn{3}{|c|}{ Calendar Interaction x Branches/Establishment } \\
\hline Control Variables: & \multicolumn{3}{|c|}{ Calendar Interaction X Ln of Population } \\
\hline Control Variables: & \multicolumn{3}{|c|}{ Calendar Interaction X COVID Death rate } \\
\hline Control Variables: & \multicolumn{3}{|c|}{ Calendar Interaction x County Median Income (2018) } \\
\hline Control Variables: & \multicolumn{3}{|c|}{ Calendar Interaction X Share College } \\
\hline Control Variables: & \multicolumn{3}{|c|}{ Calendar Inteaction x Share 20-44 years of age } \\
\hline Control Variables: & \multicolumn{3}{|c|}{ Calendar Interaction x Local Unemployment in 2019} \\
\hline Observations & 430,519 & 347,730 & 21,476 \\
\hline R-squared & 0.578 & 0.665 & 0.918 \\
\hline
\end{tabular}

